\title{
IMPLIED CONSUMER REMEDY UNDER FTC TRADE REGULATION RULE- COUP DE GRÂCE DEALT HOLDER IN DUE COURSE?
}

I. Introduction $\ldots \ldots \ldots \ldots \ldots \ldots \ldots \ldots \ldots . \ldots \ldots$

II. Consumer Caught in the Holder's Grasp ....... 879

A. The Holder-in-Due-Course Doctrine .......... 879

B. State Judicial and Legislative Developments ........ 881

III. Federal Legislative and Agency Developments .. 884

A. FTC Regulation of Deceptive Trade Practices-The

Otierall Enforcement Scheme .............. 884

B. Rule Currently' in Effect ................ 887

C. Proposed Amendment to the Rule ............ 892

D. Consumer Relief for Noninclusion of the Required Notice ............................. 894

IV. Implication of a Federal Right to Raise Claims ANd DefEnses ...................... 896

A. The Implication Doctrine ............. 896

B. Implied Remedy Under Section 5 of the FTC Act-The Precedents ................... 897

C. Implied Private Remed, Under the FTC Rule .... 904

1. Unique Procedural Posture ............ 904

2. Application of the Cort Test ......... 906

a. Especial Benefit ................. 906

b. Intent to Deny' a Pritiate Remedy ........ 907

c. Consistency with the Legislatitie Scheme .... 908

d. Federalism Concerns ............... 914

V. Impact of the FTC Rule on State Law Remedies 915

VI. Conclusion ....................... 917

\section{INTRODUCTION}

Consumer buys or leases goods or services from Seller and signs a sales agreement. Consumer also signs a negotiable instrument, ${ }^{1}$ which Financer purchases from Seller, containing

1 The Uniform Commercial Code, which has been adopted in all fifty states (Louisiania has adopted Articles 1, 3, 4, and 5), the District of Columbia, and the Virgin Islands, J. Honnold, Cases and Materials on the law of Sales and Sales Financing 5 (4th ed. 1976), defines "negotiable instrument" as follows: 
Consumer's agreement to make installment payments for the goods or services. Upon discovery that the goods or services are of inferior quality, Consumer ceases payment. Financer then sues Consumer in state court for nonpayment of the installments. The court refuses to reach the merits of Consumer's defense; instead it rules summarily in favor of Financer, ${ }^{2}$ who, by virtue of possessing the negotiable instrument signed by Consumer, sued in the capacity of a holder in due course, immune to all but a few "real" defenses. ${ }^{3}$ Consumer must pay Financer and in some cases will not have even the consolation of recourse against Seller, who may turn out to be judgment proof. ${ }^{4}$

Any writing to be a negotiable instrument within this Article must

(a) be signed by the maker or drawer; and

(b) contain an unconditional promise or order to pay a sum certain in money and no other promise, order, obligation or power given by the maker or drawer except as authorized by this Article; and

(c) be payable on demand or at a definite time; and

(d) be payable to order or to bearer.

U.C.C. § 3-104(1). Consumer's obligation to pay in installments is written in the form of a negotiable instrument in a writing distinct from the agreement of sale. In line with common practice, however, the two writings may be attached to one another by perforation. Both writings are signed separately by the Consumer. Thus, although the agreement of sale contains other conditions and promises-for example, Seller's warranties-the writing embodying Consumer's obligation, containing only an unconditional promise to pay, qualifies as a negotiable instrument.

${ }^{2}$ In the case of goods, Consumer often will give Seller a security interest in the goods. This security interest is sold with the note to Financer. Rohner, Holder in Due Course in Consumer Transactions: Requiem, Revival, or Reformation?, 60 CORNELL L. REV. 503, 506-07 (1975). Financer often can attempt to repossess the goods, without suit, upon Consumer's default. Nonetheless, preservation of Consumer's defenses is important because Financer often will seek either a judgment on the debt before attempting to foreclose the security interest or, having foreclosed the security interest and sold the goods, judgment for any deficiency. See, e.g., Westinghouse Credit Corp. v. Chapman, $129 \mathrm{Ga}$. App. 830, 201 S.E.2d 686 (1973). Thus, Consumer would still need the defenses he could assert against his seller. Moreover, Consumer may wish to block Financer's seizure of the goods securing the note by suing Financer. See, e.g., Fuller v. American Aluminum Corp., 249 So. $2 \mathrm{~d} 410$ (Miss. 1971). In such a case, the defenses Consumer could assert against Seller would be essential to any successful action against Financer. For purposes of discussion, this Comment treats as the paradigm situation one in which Financer sues Consumer on the underlying debt.

${ }^{3}$ According to the U.C.C., a holder in due course takes a negotiable instrument free from all "personal defenses" such as failure or lack of consideration, breach of warranty, unconscionability, or fraud in the inducement. For policy reasons, "real defenses," such as infancy, duress, and fraud in the factum, are preserved and may be raised by the maker against a holder in due course. U.C.C. § 3-305(2); see J. WhITE \& R. Summers, Handbook of the Law UNder the Uniform Commercial Code 486-89 (1972) [hereinafter cited as Whrte \& SUMmers].

${ }^{4}$ See, e.g., Vasquez v. Superior Court, 4 Cal. 3d 800, 484 P.2d 964, 94 Cal. Rptr. 976 (1971):

In the instant case, as in many situations in which consumers have been defrauded by a seller, a judgment against the seller alone would represent a Pyrrhic victory because the defrauding seller is insolvent and the victorious con- 
The foregoing scenario unfortunately is not an uncommon one. ${ }^{5}$ The holder-in-due-course doctrine, which originally developed in the context of commercial paper markets, ${ }^{6}$ has drawn extensive criticism when applied to consumer transactions. ${ }^{7}$ State courts and legislatures, sensitive to the consumers' plight, have made diverse attempts to combat the inequity of the doctrine as it applies to consumers, but have not achieved great success. ${ }^{8}$ Predictions of its demise notwithstanding, ${ }^{9}$ the holder-in-duecourse doctrine has proven to be a resilient concept that continues to pose a problem to consumers. ${ }^{10}$ Still another consumer champion may succeed, however, in dealing it the "coup de grâce." The Federal Trade Commission (FTC) has promulgated a trade regulation rule ${ }^{11}$ designed to preserve a consumer's right to assert against a financer who holds an otherwise negotiable instrument any claims or defenses that the consumer might assert against his seller-nondelivery, breach of warranty, or other personal defense. ${ }^{12}$ The rule seeks to accomplish its purpose by

sumers remain liable to the finance companies, which as the assignees of the installment contracts claim that they are entitled to payment even if the seller acted fraudulently.

Id. at 821-22, 484 P.2d at 978, 94 Cal. Rptr. at 810. "Predatory" sellers may engage either in business-on-a-shoestring or in fly-by-night operations, so that when consumers wish to seek recourse against them, the businesses already may have failed or left town. Similarly, if the seller was a short-lived corporation, the corporation may be defunct when consumers seek relief against it.

${ }^{5}$ See Speaker, Holder in Due Course-Burden of the Poor, 5 U.C.C. L.J. 146 (1972).

${ }^{6}$ See Gilmore, The Commercial Doctrine of Good Faith Purchase, 63 YALE L.J. 1057 (1954); Littlefield, Good Faith Purchase of Consumer Paper: The Failure of the Subjective Test, 39 S. CAL. L. Rev. 48, 49 (1966).

'See, e.g., Gilmore, supra note 6; Littlefield, supra note 6; Rohner, supra note 2; Rosenthal, Negotiability -Who Needs It?, 71 Colum. L. Rev. 375 (1971).

${ }^{8}$ See notes 28-44 infra \& accompanying text.

${ }^{9}$ See Leary, Timely Demise of Holder in Due Course Doctrine, 5 U.C.C. L.J. 117, 119 (1972). See also Erickson, Demise of Holder in Due Course, Waiver of Defense, and Interlocking Loan Lender Defenses in Consumer Transactions, 15 S. TEx. L.J. 236 (1974); Litulefield, The Continuing Demise of the Holder in Due Course Concept, 79 Com. L.J. 41 (1974).

${ }^{10}$ Rohner, supra note 2 , at 566-67.

${ }^{11}$ Preservation of Consumers' Claims and Defenses, 16 C.F.R. \$ 433 (1976). Upon promulgation of the rule, the FTC issued a Statement of Basis and Purpose, 40 Fed. Reg. 53, 506-29 (1975) [hereinafter cited as FTC Statement], and later issued Guidelines on Trade Regulation Rule Concerning Preservation of Consumers' Claims and Defenses, 41 Fed. Reg. 20,022-27 (1976) [hereinafter cited as Guidelines] and a Statement of Enforcement Policy, 41 Fed. Reg. 34,594-97 (1976) [hereinafter cited as Enforcement Policy]. The voluminous collection of statements, articles, memoranda, correspondence, and exhibits and the oral testimony from the 1971 and 1973 FTC hearings on an earlier version of the rule are paginated consecutively within a single FTC document. FTC Record and Transcript of Hearings on Proposed Trade Regulation Rule, No. 215-31-1 (F.T.C., Jan. 26, 1971).

12 Under the rule, a consumer's recovery on a claim asserted against a financer is 
requiring sellers to include in agreements of sale a notice to holders that a consumer's claims and defenses may be asserted against them. ${ }^{13}$

When the notice required by the FTC rule is included in the consumer credit contract the inequitable result of the introductory scenario will not obtain. ${ }^{14}$ This Comment explores the impact of the rule on the adjudication of disputes arising between a consumer and a financer in connection with consumer credit contracts that, contrary to the direction of the rule, do not include the notice to holders. ${ }^{15}$ Part II will detail the problem facing consumers and consider state judicial and legislative responses to it. Part III will examine the FTC rule in relation to the general scheme for regulating deceptive trade practices under the Federal Trade Commission Act (Act). ${ }^{16}$ Part IV will weigh the arguments for and against the view that when the required notice is not included, the FTC rule creates for the consumer an implied federal right to assert claims and defenses against the holder of this consumer credit contract. Part V considers the effect that state courts might give to the rule as a matter of state law even in the absence of an implied federal right.

\section{Consumer Caught in the Holder's Grasp}

\section{A. The Holder in Due Course Doctrine}

A holder in due course is the possessor of a written, unconditional promise of payment - that is, a negotiable instrument ${ }^{\mathbf{1 7}}$ -taken for value, in good faith, and without notice that it is overdue or has been dishonored or of any defense against or claim to it on the part of any person. ${ }^{18}$ Such a holder is in the privileged position of holding the instrument free from all ownership claims of third parties and being able to enforce its obliga-

limited to the amount paid under the credit instrument. FTC Statement, supra note 11, at 53,524; Guidelines, supra note 11, at 20,023.

${ }_{13}$ Alternatively, had a seller referred the consumer to a financer for a direct loan to finance the sale, the seller would be required to refuse the loan proceeds unless the notice to holders had been included in the loan agreement. FTC Statement, supra note 11, at 53,524-25; Guidelines, supra note 11, at 20,023-24.

${ }^{14}$ See text accompanying notes 63-69 infra.

15 The major inspiration for this Comment is J. Honnold, supra note 1 , at 731-40.

${ }^{16} 15$ U.S.C. $\$ \S 41-46,47-58$ (1970 \& Supp. V 1975).

${ }^{17}$ U.C.C. $\$ 3-104(1)$. This section of the Code is set forth at note 1 supra.

${ }^{18}$ U.C.C. $\$ 3-302(1)$. 
tion against nearly any defense. ${ }^{19}$ The risk of loss thus is shifted from the holder of the instrument to its maker. ${ }^{20}$ The policy justification for this allocation of risk is that it promotes the availability of credit essential to healthy commerce. ${ }^{21}$ Furthermore, because all merchants benefit from freely flowing commerce, having the makers of paper bear the risk of obtaining credit is an equitable allocation of this risk, at least among merchants. ${ }^{22}$ When the maker is a consumer, however, significantly different equitable considerations enter the picture. The consumer transaction is centered around a particular purchase of a good of service, which puts the typical consumer in a poor position to insure against loss or spread its costs. ${ }^{23}$ Nevertheless, the same legal framework developed to meet the needs of commercial paper markets has been imposed, to the detriment of consumers, on transactions in consumer paper. ${ }^{24}$

In the introductory scenario, Financer enjoyed protected status as a holder in due course of the negotiable note Consumer had made out to Seller. Two other methods would have placed Financer in a legally equivalent position. In many jurisdictions,

19 U.C.C. $\$ 3-305$. For examples of "real" defenses preserved against holders in due course, see note 3 supra. at 376 .

20 Rohner, supra note 1, at 505; see Gilmore, supra note 6; Rosenthal, supra note 7,

${ }^{21}$ The policy of promoting economic efficiency in commercial paper transactions, therefore, favors placing the risk of loss on the maker of paper. See White \& Summers, supra note 3, at 457; Rohner, supra note 2, at 528; Rosenthal, supra note 7, at 376-77.

${ }^{22}$ See Littlefield, supra note 6, at 48 .

${ }^{23}$ As eloquently stated by Prof. Gilmore:

The privilege which commercial law confers upon the purchaser in good faith or his alter ego, the holder in due course, is, always and everywhere, a commercial privilege. It attaches to commercial property and to transactions between merchants. Consumer installment purchase is a commercial phenomenon of considerable magnitude. But from the consumer's point of view the transaction is not mercantile for the goods are no longer in commerce; they have come to rest and become mere possessions. The inequality of bargaining power and technological knowledge between consumer and dealer justifies the conclusion .... that claims against the consumer will not, like ordinary commercial claims, be allowed to pass free of defenses.

Gilmore, supra note 6, at 1101 ; see FTC Statement, supra note 11 , at 53,522-24; Littlefield, supra note 6, at 48-49; Rohner, supra note 2, at 538-43; Rosenthal, supra note 7, at 379-81. For the holder to bear the risk in consumer credit transactions is not only more equitable, but also more efficient. See text accompanying notes 72-84 infra.

${ }^{24}$ The law governing the good faith purchase of commercial paper had developed fully before the advent of consumer paper onto the credit scene. Thus, when faced with cases arising out of consumer credit-sale transactions, the courts naturally turned to the existing body of law. Gilmore, supra note 6, at 1093-1102; Littlefield, supra note 6 , at 60 . For adjustments that the courts made in implicit recognition of the fundamentally different nature of credit transactions involving noncommercial parties, see notes 28-38 infra \& accompanying text. 
assignment to Financer of an agreement of sale incorporating a waiver of defense clause would have provided immunity from Consumer's claims and defenses. ${ }^{25}$ There would have been a similar result had Consumer been "referred" by Seller to Financer to obtain a direct loan to finance the sale. Referral relationships in these "interlocking loans" run the gamut from simple referral to the situation in which Seller accompanies Consumer to Financer's office and there accepts the proceeds of the loan immediately after the papers are drawn up. ${ }^{26}$ Despite a close "referral" relationship and the appearance to Consumer of a unified transaction, the sale and the loan generally are considered to be discrete transactions, and Consumer's obligation to Financer would be enforceable independently of his claims against Seller. ${ }^{27}$

\section{B. State Judicial and Legislative Developments}

The three methods by which financers are made secure from consumers' claims and defenses-the negotiable consumer note, the waiver of defense clause, and the interlocking loan - have been subjected to varying degrees of regulation by state courts and legislatures. As three aspects of the same problem, they logically should be treated in a consistent fashion.

Although judicial protection extended in this area usually has been for the benefit of the consumer, judicial response to the different cut-off devices has been uneven. Although a few courts have invalidated waiver of defense clauses either as unconscionable or as contrary to public policy ${ }^{28}$ and one court has held that retail installment contracts simply are not negotiable instruments, ${ }^{29}$ most courts have been reluctant to go so far. Under the "close connectedness" doctrine, courts have denied holder-in-due-course status to financer-assignees of consumer paper when they were too closely connected with the seller507-08.

${ }^{25}$ FTC Statement, supra note 11, at 53,508 \& 53,509-14; Rohner, supra note 2, at

${ }^{26}$ FTC Statement at 53,508 \& 53,514-16; see Littlefield, Preserving Consumer Defenses: Plugging the Loophole in the New UCCC, 44 N.Y.U. L. REv. 272 (1969); Rohner, supra note 2, at 508 .

${ }^{27}$ Interlocking loans are also sometimes called "vendor-related" loans. See FTC Statement, supra note 11 , at 53,508 .

${ }^{28}$ E.g., Fairfield Credit Corp. v. Donnelly, 158 Conn. 543, 264 A.2d 547 (1969); see Rehurek v. Chrysler Credit Corp., 262 So. 2d 452 (Fla. App. 1972); Unico v. Owen, 50 N.J. 101, 232 A.2d 405 (1967); Discount Purchasing Co. v. Porch, 12 U.C.C. Rep. Serv. 600 (Tenn. App. 1973).

${ }^{29}$ Geiger Fin. Co. v. Graham, 123 Ga. App. 771, 182 S.E.2d 521 (1971). 
assignors. ${ }^{30}$ Elements indicating close connection include drafting by the financer of forms for the seller, the seller's assignment of substantially all of his paper to the same financer, and common ownership or management of seller and financer. ${ }^{31} \mathrm{Al}-$ though the legal rationale of the doctrine is unclear, it seems to grow out of the notice and good faith requirements of holderin-due-course status. ${ }^{32}$ For purposes of "close connectedness," the seller may be characterized as the financer's agent, whose notice of the consumer's defenses can be imputed to the principal. ${ }^{33}$ Sometimes the financer is said to lack the requisite good faith because of close dealing with the seller. ${ }^{34}$ Another possible rationale is that the "oneness" of the financer and seller requires that both be subject to the consumer's defenses as a matter of primary liability. ${ }^{35}$ Several state courts have made significant retreats from earlier, liberal applications of the close connectedness doctrine, ${ }^{\mathbf{3 6}}$ which even in its most liberal strains rather narrowly restricts the class of relationships that qualify as "close connections." ${ }^{37}$ In any case, judicial protection has never gone so far as to include the informal referral relationships that underlie interlocking loan transactions. ${ }^{38}$

${ }^{30}$ E.g., Commercial Credit Co. v. Childs, 199 Ark. 1073, 137 S.W.2d 260 (1940); Commercial Credit Corp. v. Orange County Machine Works, 34 Cal. 2d 766, 214 P.2d 819 (1950); Jones v. Approved Bancredit Corp., 256 A.2d 739 (Del. 1969); Calvert Credit Corp. v. Williams, 244 A.2d 494 (D.C. App. 1968); Mutual Fin. Co. v. Martin, 63 So. 2d 649 (Fla. 1953); Unico v. Owen, 50 N.J. 101, 232 A.2d 405 (1967); American Plan Corp. v. Woods, 16 Ohio App. 2d 1, 240 N.E.2d 886 (1968).

${ }^{31}$ WhITE \& Summers, supra note 3 , at 481.

${ }^{32}$ See id. 480.

${ }^{33}$ See id.; Littlefield, supra note 6, at 67-68.

${ }^{34}$ See WhiTe \& Summers, supra note 3 , at 480 ; Littlefield, supra note 6 , at 70-74.

${ }^{35}$ See White \& Summers, supra note 3, at 480; Littlefield, supra note 6, at 68-70.

${ }^{36}$ See Rohner, supra note 2, at 517-21. Compare Sullivan v. United Dealers Corp., 486 S.W.2d 699 (Ky. 1972) and Block v. Ford Motor Credit Co., 286 A.2d 228 (D.C. App. 1972) (applying Maryland law), with Massey-Ferguson, Inc. v. Utley, 439 S.W.2d 57 (Ky. 1969) and Kennard v. Reliance, Inc., 257 Md. 654, 264 A.2d 832 (1970). See also Randolph Nat'l Bank v. Vail, 131 Vt. 390, 308 A.2d 588 (1973) (circumvention of statute limiting holder-in-due-course protection).

${ }^{37}$ See cases cited at notes 30-3I supra.

${ }^{38}$ See, e.g., Sullivan v. United Dealers Corp., 486 S.W.2d 699 (Ky. 1972). Illustrative of the judicial leeway granted such referral relationships is the court's explanation of upholding holder-in-due-course protection:

The evidence failed to demonstrate any direct connection between the contractor and the finance company except a frequent course of dealing between them. In short, the evidence failed to demonstrate any bad faith on the part of the finance company at the time of the negotiation and transfer of the note to it. All of the evidence demonstrated a complete lack of notice to the finance company that would justify a finding that it failed to acquire the status of a holder in due course.

Id. at 701-02 (emphasis supplied). 
Although legislatures are more competent than the courts to deal with the problem in a systematic way, they nonetheless have failed to do so. ${ }^{39}$ The lack of uniformity of statutory regulation among jurisdictions is startling, and the three defense cut-off mechanisms are not equally regulated even within a given jurisdiction. As of 1972, thirty-four jurisdictions limited to some degree the use of negotiable consumer notes, thirty-seven had dealt in some fashion with waiver of defense clauses, but only six had addressed interlocking loans. ${ }^{40}$ Only twenty jurisdictions had effectively banned defense cut-offs through the use of negotiable consumer paper, and only sixteen had banned waiver of defense clauses entirely. ${ }^{41}$ The other jurisdictions that regulated these two mechanisms limited their prohibition of defense cut-offs to specific transactions or to specific time periods, after which the holder becomes a holder in due course if notice of claims or defenses has not been received from the consumer. ${ }^{42}$ In this uneven scheme of legislation, the most egregious omission is the general failure to regulate interlocking loans. ${ }^{43}$

Assessing these efforts of state courts and legislatures one commentator has said:

Holder in due course is not dead, even in its historical sense, so long as different jurisdictions treat it differently in their courts and legislatures and so long as it is not abolished root and branch in all consumer transactions-from home improvements to auto sales .... In fact, to prolong the metaphor, holder in due course is not a single organism slayable in a single blow. It is a collection of legal traditions and rules and commercial practices which merge into a single result: the insulation of financers from consumer claims. No as-

${ }^{39}$ Regarding a recent federal statute limiting the application of the holder-in-duecourse doctrine in credit card transactions, Depository Institutions Amendments of 1974, Pub. L. No. 93-495, tit. III, $\S 170,88$ Stat. 1500 (1974) (codified at 15 U.S.C. $\$ \S 1601-1691$ (Supp. IV 1974), see Rohner, supra note 2, at 504 \& n.11, 508-09, 521, 526-27. See generally Littlefield, Preservation of Consumer Defenses in Interlocking Loans and Credit Card Transactions-Recent Statutes, Policies, and a Proposal, 1973 WIs. L. Rev. 471. The ramifications of the holder-in-due-course doctrine in credit card transactions will not be explored in this Comment.

"See Crandall, The Wisconsin Consumer Act: Wisconsin Consumer Credit Laues Before and After, 1973 Wis. L. REv. 334 apps. 4 \& 5, at 386-94.

${ }^{41}$ Id.

${ }^{42}$ Willier, Need for Preservation of Buyers' Defenses - State Statutes Reviewed, 5 U.C.C. L.J. 132 (1972). For an update of the 1972 compilation of statutes, see Rohner, supra note 2 , at 522 n.90.

${ }^{43}$ See Littlefield, supra note 26 , at 286-97. 
sault on the doctrine can therefore succeed unless it is both comprehensive and uniform, and the impetus for such an attack may need to come from the federal level. ${ }^{44}$

The FTC rule is just such a federal initiative. This Comment will proceed to sketch the backdrop of the rule-the Act's scheme for regulating deceptive trade practices-and then examine its specific provisions.

\section{Federal Legislative and Agency Developments}

\section{A. FTC Regulation of Deceptive Trade Practices- The Overall Enforcement Scheme}

Section $5(\mathrm{a})(\mathrm{l})$ of the Act ${ }^{45}$ declares "[u]nfair methods of competition in or affecting commerce, and unfair or deceptive acts or practices in or affecting commerce" to be unlawful. As originally enacted in 1914, the prohibition applied only to "unfair methods of competition." ${ }^{6}$ The language prohibiting deceptive trade practices was added by the Wheeler-Lea Amendments of $1938^{47}$ in order to overrule a Supreme Court decision confining the reach of section 5 to acts having an adverse competitive impact. ${ }^{48}$ The addition evidenced a clear intention to make consumer protection a primary purpose of the Act: "[T] $]$ his amendment makes the consumer, who may be injured by an unfair trade practice, of equal concern, before the law, with the merchant or manufacturer injured by the unfair methods of a dishonest competitor." 49

Section 5(b) authorizes the FTC to initiate cease and desist proceedings against violators of section $5(\mathrm{a})(1)$ if, in the agency's view, such prosecution is in the public interest. ${ }^{50}$ Until recently, aside from seeking voluntary compliance, the FTC was limited to cease and desist proceedings in fulfilling the enforcement role

${ }^{44}$ Rohner, supra note 2, at 566-67.

4515 U.S.C. $\$ 45(a)$ (1) (Supp. V 1975).

4638 Stat. 719 (1914) (current version at 15 U.S.C. $\$ 45(a)$ (1) (Supp. V 1975)).

${ }^{47} 52$ Stat. 111 (1938) (current version at 15 U.S.C. $\$ 45$ (a)(I) (Supp. V 1975)).

${ }^{48}$ FTC v. Raladam Co., 283 U.S. 643 (1931).

${ }^{49}$ H.R. ReP. No. 1613, 75th Cong., 1st Sess. 3 (1937). See Lovett, Private Actions for Deceptive Trade Practices, 23 AD. L. REv. 271, 274 (1971); Note, Implied Civil Remedies for Consumers Under the Federal Trade Commission Act, 54 B.U. L. Rev. 758, 762 (1974); Comment, Consumer Protection: Proposed Federal Trade Commission Rule-Preservation of Buyers' Claims and Defenses in Consumer Installment Sales, 21 J. PuB. L. 169 (1972). But see Holloway v. Bristol-Myers Corp., 485 F.2d 986 (D.C. Cir. 1973). Many states were inspired to enact "Little FTC Acts." See Lovett, supra, at 275, 281-90.

50 15 U.S.C. $\$ 45($ b) (Supp. V 1975). 
assigned it. The FTC's record in enforcing the section 5 proscription of deceptive trade practices was poor. ${ }^{51}$ This ineffectiveness has been traced to lack of planning, misallocation of scarce resources, delay, excessive reliance on voluntary compliance, and lack of meaningful sanctions. ${ }^{52}$

Criticism of the FTC's performance provided part of the impetus for the Magnuson-Moss Federal Trade Commission Improvement Act of 1975 (1975 Act), ${ }^{53}$ which endowed the agency with improved weapons to combat consumer fraud..$^{54}$ The 1975 Act authorized the FTC to promulgate trade regulation rules "which define with specificity acts or practices which are unfair or deceptive acts or practices in or affecting commerce" 55 and empowered it to enforce these rules by civil actions in which consumer redress is to be available. ${ }^{56}$ The 1975

51 See, e.g., Guernsey v. Rich Plan, 408 F. Supp. 582, 586-88 (N.D. Ind. 1976);

Report of the ABA Commission to Study the Federal Trade Commission (1969)

[hereinafter cited as ABA Report]; E. Cox, R. Fellmeth, \& J. Schultz, 'The Nader

Report' on the Federal Trade Commission (1969); Note, supra note 49, at 763-65;

Comment, supra note 49 , at 169-73.

52 ABA RePORT, supra note 51, at 34-35, 54-55, 62-63; see Note, supra note 49, at 763-74.

s3 Pub. L. No. 93-637, 88 Stat. 2193 (1975) (codified in scattered sections of 15 U.S.C.).

54 Id. tit. II. Title I of the 1975 Act dealt with federal warranty standards, see note 168 infra. In 1973, the Act was amended to empower the FTC to obtain a preliminary injunction from a district court against alleged violations of the Act. Act of Nov. 16, 1973 , Pub. L. No. 93-153, § 408(f), 87 Stat. 576 (codified at 15 U.S.C. $\S 53$ (b) (Supp. V 1975)).

${ }^{53} 15$ U.S.C. $\$ 57 \mathrm{a}(\mathrm{a})(1)(\mathrm{B})$ (Supp. $\mathrm{V}$ 1975). Rules promulgated under this subparagraph "may include requirements prescribed for the purpose of preventing such [unfair or deceptive] acts or practices." Id. Banks are excluded from the FTC's jurisdiction. 15 U.S.C. $\$ 45(a)(6)(1970)$. The 1975 Act requires, however, that within 60 days after the effective date of a deceptive trade practice rule promulgated by the FTC, the Federal Reserve Board "shall promulgate substantially similar regulations" prohibiting "substantially similar" acts or practices by banks unless the Board finds that "(A) such acts or practices of banks are not unfair or deceptive, or (B) that implementation of similar regulations with respect to banks would seriously conflict with essential monetary and payments systems policies of the Board . ..." 15 U.S.C. \& 57a(f)(1) (Supp. V 1975). The Board has not promulgated a "substantially similar" regulation to the FTC preservation of claims and defenses rule because in its current version the rule is not enforceable against creditors. Text accompanying note 62 infra. The proposed amendment to the rule, however, is enforceable against creditors. Text accompanying notes 94-95 infra. Aware that a substantially similar regulation applicable to banks thus may become necessary if the FTC promulgates its proposed revision, the Board has published notice to the banking community seeking reactions and input. 41 Fed. Reg. 7,110-11 (1976).

${ }^{56} 15$ U.S.C. $\$ 57 b(b)$ (Supp. V 1975). The nature of relief available in an FTC civil action includes

such relief as the court finds necessary to redress injury to consumers or other persons, partnerships, and corporations resulting from the rule violation or the unfair or deceptive act or practice, as the case may be. Such relief may include, 
Act did not, however, create an explicit private right of action against deceptive trade practices. ${ }^{57}$

Improvements notwithstanding, criticism continues to be leveled that sole reliance on the FTC is inadequate to assure proper regulation of deceptive trade practices. ${ }^{58}$ There is room

but shall not be limited to, rescission or reformation of contracts, the refund of money or return of property, the payment of damages, and public notification respecting the rule violation or the unfair or deceptive act or practice, as the case may be; except that nothing in this subsection is intended to authorize the imposition of any exemplary, or punitive damages.

Id. Other important provisions of the 1975 Act include expanding the FTC's jurisdiction to include trade practices "in or affecting commerce," 15 U.S.C. \& 45(a)(1) (Supp. V 1975), and authorizing the agency to seek civil penalties for knowing violations of its rules and cease and desist orders respecting unfair or deceptive trade practices, 15 U.S.C. $\S 45(\mathrm{~m})$ (Supp. V 1975). For basic source material on the 1975 Act, see [1974] U.S. Code Cong. \& Ad. News 7702-75; Kintner \& Smith, The Emergence of the Federal Trade Commission as a Formidable Consumer Protection Agency, 26 MERCER L. Rev. 651 (1975); Note, The Magnuson-Moss Amendments to the Federal Trade Commission Act: Improvements or Broken Promises?, 6I Iowa L. Rev. 222 (1975).

${ }^{57} \mathrm{~A}$ private right of enforcement was recommended in ABA RePORT, supra note 51, at 63-64. Predecessors to the bill that ultimately was enacted in 1975 did contain provisions creating such a right, but they died in committee or were never brought to a vote on the floor before the end of the respective Congresses in which they were introduced. E.g., S. 1823, 92d Cong., 1st Sess., 117 CoNG. Rec. 14298 (1971) (referred to the Committee on Commerce where it died, never being reported out before the end of the 92d Congress); S. 3201, 91st Cong., 1st Sess., 115 Cong. REc. 36598-600 (1969) (reported out of Committee on Commerce with amendments, S. REP. No. 1124, 91st Cong., 2d Sess. (1970), and referred to Committee on the Judiciary, 116 Cong. REC. 29006 (1970), reported out of the Committee on the Judiciary without recommendation, 116 ConG. REc. 34898 (1970) (the original version provided for private action only after the FTC had issued a cease and desist order; the amendments of the Committee on Commerce provided, in addition, for consumer class actions against deceptive trade practices with no requirement of prior FTC action; the bill was never brought to a floor vote in the Senate before the end of the 91st Congress)); S. 3092, 91st Cong., Ist Sess., 115 Cong. Rec. 32141-42 (1969) (provided for consumer class actions; referred to Committee on Commerce and never reported out before the end of the 91st Congress); H.R. 14931, 91st Cong., 1st Sess., 115 Cong. REc. 35275 (1969) (provided for both private and class actions; died in the Committee on Interstate and Foreign Commerce); H.R. 14832, 91 st Cong., 1st Sess., 115 Cong. REc. 34374 (1969) (same). Lovett, supra note 49 , at $279-80$, explains that these proposals for private remedies were the victims of crossfire between consumer protection enthusiasts and business interests opposing even the more conservative provision for private action subsequent to an FTC cease and desist order. See also Note, supra note 49 , at $759 \&$ n.7.

${ }^{58}$ Guernsey v. Rich Plan, 408 F. Supp. 582 (N.D. Ind. 1976):

The ineffectiveness of the Federal Trade Commission was argued in the Holloway case. . . . While complaints of this nature have become more frequent, Congress has not seen fit to alter the basic statutory plan as it was amended in 1938. The Magnuson-Moss Warranty-Federal Trade Commission Improvement Act . . expanded consumer remedies but does not alter the Federal Trade Commission Act as it relates to suits of this type.

Id. at 587 (citations omitted). See ABA REPORT, supra note 51, at 114-18 (in his statement, R. Posner expressed strong doubts whether the proposed improvements would indeed improve the FTC's performance in the consumer protection area); Note, supra note 56, at 223 n.8, 258-59. 
for doubting whether substantial relief will be forthcoming to consumers as a consequence of the new provision permitting consumer redress litigation. ${ }^{59}$

\section{B. Rule Currently in Effect}

The specific language of the FTC rule in effect since May 14,1976 , is as follows:

In connection with any sale or lease of goods or services to consumers, in or affecting commerce as "commerce" is defined in the Federal Trade Commission Act, it is an unfair or deceptive act or practice within the meaning of Section 5 of that Act for a seller, directly or indirectly, to:

(a) Take or receive a consumer credit contract which fails to contain the following provision in at least ten point, bold face, type:

\section{NOTICE}

ANY HOLDER OF THIS CONSUMER CREDIT CONTRACT IS SUBJECT TO ALL CLAIMS AND DEFENSES WHICH THE DEBTOR COULD ASSERT AGAINST THE SELLER OF GOODS OR SERVICES OBTAINED PURSUANT HERETO OR WITH THE PROCEEDS HEREOF. RECOVERY HEREUNDER BY THE DEBTOR SHALL NOT EXCEED AMOUNTS PAID BY THE DEBTOR HEREUNDER.

or, (b) Accept, as full or partial payment for such sale or lease, the proceeds of any purchase money loan (as purchase money loan is defined herein), unless any consumer credit contract made in connection with such purchase money loan contains the following provision in at least ten point, bold face, type:

NOTICE

ANY HOLDER OF THIS CONSUMER CREDIT CONTRACT IS SUBJECT TO ALL CLAIMS AND DEFENSES WHICH THE DEBTOR COULD ASSERT AGAINST THE SELLER OF GOODS OR

${ }^{59}$ See Maher, Two Little Words and FTC Goes Local, 80 Dick. L. REv. 193 (1976): Honesty compels admitting a certain skepticism about consumer redress litigation beyond meaningful consumer control. Those provisions have all the earmarks of becoming little more than a tool with which to coerce early submission of respondents. If this proves correct, their actual use will be infrequent and must prove an irritant to professional consumerists who inevitably will decry underutilization.

Id. 197. 
SERVICES OBTAINED WITH THE PROCEEDS HEREOF. RECOVERY HEREUNDER BY THE DEBTOR SHALL NOT EXCEED AMOUNTS PAID BY THE DEBTOR HEREUNDER. ${ }^{60}$

The avowed purpose of the rule is to make it an unfair and deceptive practice within the meaning of section 5 of the Act for a seller to exploit negotiable consumer notes, waiver of defense clauses, or interlocking loans in order to separate the consumer's duty to pay from the seller's duty to fulfill his obligations. ${ }^{61}$ Significantly, the rule seeks to solve the problem of these consumer defense cut-offs by creating a duty in sellers alone, rather than subjecting both sellers and financers to its strictures. ${ }^{62}$ The rule adopts this strategy even though defense cut-offs result from the assertion by financers-not sellers-of holder-in-duecourse status vis-à-vis consumers.

The weapon the rule wields against the holder in due course is the required notice. The holder of a consumer credit contract containing it would fail to qualify as a holder in due course as a matter of state law either because its inclusion renders the promise of payment conditional or because, advised by it, the holder would not be without notice and in good faith. ${ }^{63}$ Once the notice is included in the credit contract, preservation of claims and defenses against the holder is an inevitable result of the operation of state law - the state courts must, after all, give effect to the contract as written. ${ }^{64}$

The two parts of the rule address themselves to consumer defenses cut-offs by (a) negotiable instruments or waiver of defense clauses and (b) interlocking loans, respectively. Part (a) requires that all consumer credit contracts to which a seller is a party contain the notice. Credit instruments incorporating the notice would be nonnegotiable. ${ }^{65}$ Negotiability could not be resurrected through a waiver of defense clause because the credit contract then would no longer "contain" the notice. ${ }^{66}$ Part (b) permits a seller to accept the proceeds of an interlocking ("purchase money") loan only if the financer ("creditor") has in-

${ }^{60} 16$ C.F.R. $\S 433.2$ (1976). Relevant definitions are given at 16 C.F.R. $\S 433.1$ (1976). See generally note 11 supra.

${ }^{61}$ FTC Statement, supra note 11, at 53,522-26; Guidelines, supra note 11, at 20,023.

${ }_{62}$ The proposed amendment to the rule includes creditors (such as Financer in the introductory scenario) within its scope. Test accompanying notes 94-95 infra.

${ }^{63}$ See text accompanying notes 17-18 supra; Enforcement Policy, supra note 11, at 34,595; Guidelines, supra note 11 , at 20,023-24.

${ }^{64} \mathrm{~J}$. HoNNOLd, supra note 1 , at 737.

${ }^{65}$ Text accompanying notes 63-64 supra.

${ }^{66}$ Guidelines, supra note 11 , at 20,023; see FTC Statement, supra note 11, at 53,524. 
cluded the notice ${ }^{67}$ in the consumer credit contract from which the loan issued. The definition of purchase money loan makes clear that connection between a seller and financer sufficient to trigger the operation of part (b) will be inferred from affiliation by common control, contract, or business arrangement or from a referral relationship. ${ }^{68}$ In making a continuing but informal referral relationship a sufficient basis for denying holder-in-duecourse status, the FTC rule goes well beyond even the most liberal constructions of "close connectedness" at state law. ${ }^{69}$ Nonetheless, merely providing information on sources of credit, or even suggesting to customers on a regular basis that credit might be available from a particular financer, does not constitute referral within the meaning of the rule; a referral relationship, however informal, must be characterized by the seller and financer's concerted or cooperative conduct that channels the consumer to the given source of credit. ${ }^{70}$ Where there is no mutually beneficial relationship with the financer, the rule would allow a seller to accept the proceeds of a loan issuing from a credit contract that omits the notice to holders. ${ }^{71}$

The traditional justification of the holder-in-due-course doctrine is its efficient and equitable allocation of risk in commercial paper markets. ${ }^{\mathbf{7 2}}$ In the interest of efficiency, the risk of loss should be placed on the party best able to prevent or distribute that risk. $^{73}$ The holder-in-due-course doctrine places the risk that the seller will fail to perform contractual obligations squarely on the shoulders of the consumer in order to assure a continuing flow of credit from financers who, in theory, would

${ }^{67}$ The notice required by part (b) omits three words-PURSUANT HERETO OR-contained in the part (a) notice. The FTC states, however, that both notices have exactly the same legal effect: the creditor stands in the shoes of the seller. Guidelines, supra note 11 , at 20,023 . The text, therefore, does not distinguish between the two notices and refers to either by the same expression: "required notice" or "notice to holders."

6816 C.F.R. $\S 433.1$ (d) (1976). For the FTC's construction of "affiliation" and "referral," see Enforcement Policy, supra note 11, at 34,595-96; Guidelines, supra note 11, at $20,025-26$.

${ }^{69}$ See note 38 supra \& accompanying text.

70 See Enforcement Policy, supra note 11, at 34,596.

${ }^{71}$ Id.; Guidelines, supra note 11 , at 20,025. Without more, an ongoing procedure whereby a seller assists a financer in perfecting security interests in goods that are bought from the seller with the proceeds of direct loans from the financer does not constitute a "business arrangement" or other form of creditor affiliation within the meaning of the rule. National Auto. Dealers Ass'n, 3 Trade Reg. Rep. (CCH) I 21,155 (June 18, 1976) (FTC advisory opinion).

${ }^{72}$ See notes 21-22 supra \& accompanying text.

${ }^{73}$ See generally G. Calabresi, The Costs of Accidents (1970). 
close their fists if they were compelled to bear this risk. ${ }^{74}$ In promulgating its rule, however, the FTC determined that because of the markedly different nature of consumer credit transactions both efficiency and equity would be served best by elimination of negotiability in the consumer context; ${ }^{75}$ that is, the financer, not the consumer, is best able to bear the risk of loss. ${ }^{76}$ Indeed, an examination of the risk allocation achieved by the holder-in-due-course doctrine in the consumer context suggests that the doctrine hinders the efficiency it is designed to promote. ${ }^{77}$ The consumer usually lacks the information and economic muscle to police seller misconduct and spread the costs. ${ }^{78}$ In contrast, the FTC explains:

The creditor financing the transaction is in a better position [to reallocate the costs of seller misconduct] than the consumer because (1) he engages in many transactions where consumers deal infrequently; (2) he has access to a variety of information systems which are unavailable to consumers; (3) he has recourse to contractual devices which render the routine return of seller misconduct costs to sellers relatively cheap and automatic; and (4) the creditor possesses the means to initiate a lawsuit and prosecute it to judgment where recourse to the legal system is necessary. ${ }^{79}$

Further, whereas a consumer cut off from his or her defenses must bear the full cost of the seller's misconduct, ${ }^{80}$ financers have the ability to "pass back" these costs to sellers by means of repurchase provisions or to "pass on" and "spread out" these costs among consumers generally by increasing the cost of credit. ${ }^{81}$ Finally, financers can cease making credit available to high risk sellers-a result that, on balance, should benefit consumers by keeping predatory sellers out of the market. ${ }^{82}$ Experi-

${ }^{74}$ See notes 20-22 supra \& accompanying text.

${ }^{75}$ FTC Statement, supra note 11, at 53,522-24.

${ }^{76}$ See id.

${ }^{77}$ See generally Rohner, supra note 2, at 527-51.

${ }^{78}$ FTC Statement, supra note 11 , at 53,523 . Significantly, the FTC found consumer credit sales to involve an adhesive bargaining process in which consumers are compelled to surrender their right to assert claims and defenses: "[p]romissory notes and waivers of defenses are presented to consumers on a take it or leave it basis." Id. at 53,523-24.

${ }^{79} I d$. at 53,523; see Rohner, supra note 2, 538-43.

${ }^{80}$ The sums in question can be substantial-the litigation involves high-cost items such as cars, home improvements, and furniture. See Speaker, supra note 5, at 147-48.

${ }^{81}$ FTC Statement, supra note 11 , at 53,518-20.

${ }^{82}$ Id. 53,520-22. See also Rohner, supra note 2, at 543. Although this would mean 
ence under state statutes eliminating negotiability in consumer contracts suggests that preservation of consumer defenses will not have a significant impact on either availability of credit or interest rates. ${ }^{83}$ In addition to these considerations, the FTC found that equity commanded the same policy: "It is unfair to subject an innocent party to costs and harm occasioned by a guilty party." 84

Notwithstanding the 1975 changes, the Act's explicit enforcement scheme still may be inadequate to achieve the policy objectives of the rule. Given only limited resources ${ }^{85}$ to allocate among its various functions, the FTC presumably will have to rely heavily on voluntary compliance by sellers. The efforts that are undertaken to enforce compliance will be significantly restricted because the enforcement sanction of the present rule reaches only sellers. ${ }^{86}$ If a credit contract omits the required notice, the FTC will not be able to prosecute ${ }^{87}$ the financer who sues the consumer while claiming the holder-in-due-course privilege. ${ }^{88}$

As a practical matter, the FTC generally will be able to discipline only large retailers and dealers who do not include the notice to holders in their installment sales agreements. Under its new authority, the FTC can bring these sellers into court and have the contracts reformed to include the notice. ${ }^{89}$ Furthermore, if financer-assignees of these contracts have collected from consumers wrongly cut off from their defenses, then the FTC will be able to collect damages from the merchants on the con-

that consumers no longer would be able to obtain credit from high risk sellers squeezed out of the market, this may be a price well worth paying. FTC Statement, supra note 11, at 53,520 .

${ }^{83}$ FTC Statement, supra note 11 , at 53,520-21.

${ }^{84} \mathrm{Id} .53,523$. Another equity consideration in consumers' favor was mentioned earlier. Negotiability in consumer transactions is unfair, because consumers simply do not view the two aspects of credit sales-the sales aspect and the credit aspect-as being separate and independently enforceable. See note 23 supra \& accompanying text.

85 The 1975 Act set ceilings on appropriations to the FTC: $\$ 42$ million for fiscal year 1974-75, $\$ 46$ million for $1975-76$, and $\$ 50$ million for 1976-77. 15 U.S.C. $\$ 57 \mathrm{c}$ (Supp. V 1975); see Note, supra note 56, at 258 \& n.313. But of. White, F.T.C.: Wrong Agency for the Job of Adjudication, 61 A.B.A.J. 1242, 1242-43 (1975) (noting the possibility of a supplemental appropriation to the FTC to support its antitrust program).

${ }^{86}$ Text accompanying note 62 supra.

${ }^{87}$ In addition to its cease and desist power, the FTC now has authority to seek preliminary injunctions or initiate civil actions against alleged violators of its regulations. See notes 50, 54, 56 supra \& accompanying text.

${ }^{88}$ For a discussion" of whether state courts will accord a financer the holder-indue-course privilege even in the absence of an implied federal right of consumers to assert claims and defenses, see notes 214-24 infra \& accompanying text.

${ }^{89} 15$ U.S.C. $\& 57 \mathrm{~b}(\mathrm{~b})$ (Supp. V 1975); see note 56 supra \& accompanying text. 
sumers' behalf. ${ }^{90}$ Given its budget constraint, however, the FTC likely will limit such consumer redress litigation to cases involving large offenders; ${ }^{91}$ those smaller offenders that the FTC does pursue may turn out to be judgment proof. ${ }^{92}$ Perhaps most importantly, under the present scheme, if the credit contract omits the notice, the consumer will not be relieved of the immediate burden of having to pay the third-party financer. The damages, if any, that the FTC recoups on the consumer's behalf will be paid only after a delay. The obligation to make initial payment, coupled with possibly a substantial delay before receipt of compensation, clearly will impose hardship upon the consumer, especially a poor one. ${ }^{93}$ Thus, inherent delays and selective FTC prosecution under the Act may fail to effectuate adequately the rule's policy of preserving consumer claims and defenses.

\section{Proposed Amendment to the Rule}

At the same time the FTC promulgated the current rule, it issued a proposal for its revision:

In connection with any Purchase Money Loan (as that term is defined in $\S 433.1$ ) or any sale or lease of goods or services, in or affecting commerce as "commerce" is defined in the Federal Trade Commission Act, it constitutes an unfair or deceptive act or practice within the meaning of Section 5 of that Act, for a seller

9" See 15 U.S.C. $\$ 57 \mathrm{~b}(\mathrm{~b})$ (Supp. V 1975); note 56 supra \& accompanying text.

${ }^{91}$ In recommending a provision allowing consumer class actions as a supplement to FTC civil actions, the Senate Committee on Commerce recognized the practical impact of agency financial limitations in its report on a predecessor of the 1975 Act, S. 3201, 91st Cong., 1st Sess. (1969):

2. The authority granted by this bill to the FTC . . . to obtain redress on behalf of the consumer remains ancillary to [its] primary function-elimination of unfair and deceptive acts and practices. The FTC ...-the [staff] and [budget] of which will inevitably remain limited-must therefore choose from among the hundreds of thousands of potential consumer actions only those limited number of cases which [its] systems of priorities identify as germane to this objective. For example, the FTC might find that a particular case involving notorious fraud, but affecting only several thousand residents of a smaller city should be rejected in favor of an action against the national advertiser whose product claims are on the borderline of deception and hence require the Commission's expert delineation. The necessity to allocate legal resources will necessarily leave unsatisfied hundreds, if not thousands, of valid cases in which consumers have suffered significant damages but which the government might choose not to prosecute.

S. ReP. No. 1124, 91st Cong., 2d Sess. 16 (1970). See generally note 57 supra.

${ }^{92}$ See note 4 supra.

${ }^{93}$ For a succinct analysis of the special inequity visited upon the poor by the holder in due course, see Speaker, supra note 5. 
or a creditor, directly or indirectly, to take or receive a consumer credit contract which fails to contain the following provision in at least ten point, boldface type:

\section{NOTICE}

ANY HOLDER OF THIS CONSUMER CREDIT CONTRACT IS SUBJECT TO ALL CLAIMS AND DEFENSES WHICH THE DEBTOR COULD ASSERT AGAINST THE SELLER OF GOODS OR SERVICES OBTAINED PURSUANT HERETO OR WITH THE PROCEEDS HEREOF. RECOVERY HEREUNDER BY THE DEBTOR SHALL BE LIMITED TO AMOUNTS PAID BY THE DEBTOR HEREUNDER. 94

The proposed amendment would subject financers, as well as sellers, to enforcement sanctions:

While the proceedings on 16 CFR 433 were primarily concerned with the commercial conduct of sellers, the record contains detailed information about related commercial practices of creditors which causes the Commission to have reason to believe that many creditors are participants in the aforesaid practice [cut-off of consumer defenses], that it is unfair and deceptive for them to engage in the practice and that the proscriptions of the rule can more effectively be enforced if creditors are subject to its provisions. Therefore, in the interest of (1) encompassing within the rule all participants in the aforesaid practice whose participation is unfair or deceptive and (2) facilitating enforcement of the rule, the Commission hereby proposes the aforesaid amendment. ${ }^{95}$

Notably, under the revision, a seller would not commit an unfair trade practice by accepting the proceeds of an interlocking loan issuing from a consumer credit contract that omits the required notice; part (b) of the current rule is dropped. Because the proposed revision explicitly makes the regulation directly enforceable against a financer who omits the notice in the first place, the need for part (b) is eliminated. Instead of attempting to reach financers through the many sellers with whom they deal, the FTG would be able to confront the financers themselves.

${ }^{94}$ FTC Statement, supra note 11 , at 53,530 . The phrase "be limited to" in the notice was changed to read "not exceed" at 41 Fed. Reg. 4,833 (1976).

${ }^{95}$ FTC Statement, supra note 11 , at 53,530 . 
On the other hand, the amendment's language stating that "it constitutes an unfair or deceptive act or practice ... for ... a creditor, directly or indirectly, to take or receive a consumer credit contract [omitting the required notice]"96 is broad enough to permit the construction that a financer commits an unfair trade practice by accepting the assignment of a purportedly negotiable consumer note or of an installment sales agreement incorporating a waiver of defense clause. In such situations the FTC can choose to pursue either the seller who omitted the notice or the financer-assignee. Because it is always the financer who enjoys holder-in-due-course status and can preclude the consumer from asserting claims and defenses, the policy goals of the rule will be more efficiently served by permitting the FTC to sue the financer. The change should be of particular value in promoting the goal of consumer compensation, because, in a suit to recoup payments made by consumers, the FTC is much less likely to find the financer to be judgment proof than it is so to find the seller. ${ }^{97}$

Although the proposed amendment thus will significantly improve the FTC's ability to realize its policy objectives, exclusive enforcement by the agency will be subject to inadequacies similar to those already identified under the current rule. ${ }^{98}$ Scarce resources will continue to limit FTC enforcement proceedings to the larger offenders, necessitating great reliance on voluntary compliance. Although the FTC will be able to sue successfully major financers to reform their consumer loan forms to include the required notice and to recoup consumer payments, smallersized violators may escape agency sanctions. Importantly, where a credit contract wrongly omits the notice, consumers still will be required to meet their obligation to pay the financer in spite of their defenses; again, given exclusive FTC enforcement, the consumer will be forced to wait on FTC litigation for recoupment that by long delays will cause significant hardship for the poor consumer.

\section{Consumer Relief for Noninclusion of the Required Notice}

Both the current rule and its proposed revision are silent regarding consumers' rights to raise claims and defenses when a

${ }^{96} I d$.

${ }^{97}$ See note 4 supra \& accompanying text.

98 Text accompanying notes 85-93 supra. 
consumer credit contract omits the required notice. ${ }^{99}$ When the notice is included, the right to raise defenses is dictated by state law. ${ }^{100}$ The argument might be made, therefore, that when the notice is omitted, although in contravention of the FTC regulation, consumers' rights also should be governed by state law. According to this argument, the only explicit federal remedy available to the consumer would be a civil action brought by the FTC.

Although certain FTC statements might seem to suggest that the rule is designed to operate through the exclusive medium of state law, ${ }^{101}$ close reading indicates that such an inference would be mistaken. Making clear that state law governs any adjudication of a credit contract in which the required notice has been included, the FTC nevertheless is silent on the issue of which law-state or federal-governs when the notice is omitted; it would be consistent with the rule's purpose of preserving consumers' claims and defenses to maintain that whereas the existence and success of such claims and defenses is a matter of state law, the right to raise them in the first place is a federal right. Complete reliance on FTC civil actions, under the circumstances described in the opening scenario, would provide only an inadequate remedy. Consumers will want the state courts to recognize and rule on the merits of their defenses in order to avoid the immediate burden of having to pay the financer. The prospect of compensation from a judgment obtained by the FTC sometime in the future-an uncertain prospect in any case-is not much of a consolation in the present. ${ }^{102}$ This Comment, therefore, next will inquire whether, in addition to the explicit right of enforcement delegated by the Act to the FTC, the courts should recognize an implied consumer right to enforce the policies of the rule.

${ }^{99}$ One state requiring notice to holders of consumer notes deals explicitly with this issue in statutory language providing that even if notice is omitted and the holder of a note is unaware that it is a consumer note, the holder is nonetheless subject to all claims and defenses arising out of the transaction. Alaska Stat. \$ 45.50.541(b) (Supp. 1976). A few other state statutes banning negotiable instruments from consumer credit sales specifically impose liability on the holder of an instrument issued in violation of the ban, even if the holder is otherwise a holder in due course. IDAHo CODE $\$ \S 28-32-403$, 28-32-404(b) (Supp. 1976); Wis. STat. § 422.406(3) (1971).

${ }^{100}$ See notes 63-64 supra \& accompanying text.

101 Enforcement Policy, supra note 11 , at 34,595; Guidelines, supra note 11 , at 20,023-24.

${ }^{102}$ See note 93 supra \& accompanying text. 


\section{Implication of a Federal Right to Raise Clatms and Defenses}

\section{A. The Implication Doctrine ${ }^{103}$}

A long line of Supreme Court decisions clearly have established that federal constitutional provisions and criminal or regulatory statutes may create implied private rights of action. ${ }^{104}$ The doctrine of implication that has grown out of these cases is founded upon the notion that although it is within the particular competence of legislatures to define rights, the courts are particularly competent to fashion remedies that adequately will vindicate those rights. ${ }^{105}$ The courts give considerable deference to the method of enforcement explicitly provided for by a statute, and they will not disturb a clear legislative intent that such means be exclusive. In the absence of clear legislative intent to exclude a private right of action, however, the courts may imply one when necessary to effectuate a statutory policy and when an implied private remedy will not impair significantly either the explicit statutory scheme of enforcement or some other statutory policy. ${ }^{106}$ If a federal statute is at issue, courts are also sensitive to federalism concerns and require that implication of a private federal remedy not invade unnecessarily an area more appropriately regulated by state law. ${ }^{\mathbf{1 0 7}}$

In Cort v. Ash, ${ }^{108}$ the most recent Supreme Court decision

${ }^{103}$ This Comment does not present a comprehensive analysis of the implication doctrine. For thorough background on the doctrine, see sources cited at note 104 infra.

${ }^{104}$ E.g., Cort v. Ash, 422 U.S. 66 (1975) (shareholders do not have implied right to enforce statutory ban on political campaign contributions by corporations); National R.R. Pass'r Corp. v. National Ass'n of R.R. Pass'rs, 414 U.S. 453 (1974) (rail passengers do not have implied right to enforce the Rail Passenger Act of 1970); Bivens v. Six Unknown Fed. Narcotics Agents, 403 U.S. 388 (1971) (citizens have an implied right to enforce the fourth amendment); J.I. Case Co. v. Borak, 377 U.S. 426 (1964) (shareholders have an implied right to enforce the Securities and Exchange Commission's proxy rules); T.I.M.E. Inc. v. United States, 359 U.S. 464 (1959) (a shipper of goods by motor carrier does not have an implied right to enforce the Motor Carrier Act); Texas \& Pacific Ry. v. Rigsby, 241 U.S. 33 (1916) (railroad employee has an implied right to enforce the Federal Safety Appliance Acts). See McMahon \& Rodos, Judicial Implication of Private Causes of Action: Reappraisal and Retrenchment, 80 DICK. L. REv. 167 (1976); Note, supra note 49; Note, Implying Civil Remedies from Federal Regulatory Statutes, 77 HARV. L. Rkv. 285 (1963); Comment, Emerging Standards for Implied Actions Under Federal Statutes, 9 U. Mich. J.L. REF. 294 (1976) [hereinafter cited as Emerging Standards]; Comment, Private Rights of Action under Amtrak and ASH: Some Implications for Implication, 123 U. PA. L. Rev. 1392 (1975) [hereinafter cited as Implications].

105 See, e.g., J.I. Case Co. v. Borak, 377 U.S. 426, $431-33$ (1964). See generally secondary sources cited at note 104 supra.

${ }^{106}$ See Cort v. Ash, 422 U.S. 66, 78 (1975).

${ }^{107} I d$.

108422 U.S. 66 (1975). 
involving the implication doctrine, the Court articulated the test for implying private rights of action under federal statutes:

In determining whether a private remedy is implicit in a statute not expressly providing one, several factors are relevant. First, is the plaintiff "one of the class for whose especial benefit the statute was enacted," that is, does the statute create a federal right in favor of the plaintiff? Second, is there any indication of legislative intent, explicit or implicit, either to create such a remedy or to deny one? Third, is it consistent with the underlying purposes of the legislative scheme to imply such a remedy for the plaintiff? And finally, is the cause of action one traditionally relegated to state law, in an area basically the concern of the States, so that it would be inappropriate to infer a cause of action based solely on federal law? ${ }^{109}$

This Comment will now proceed to apply the Cort test to the issue of private enforcement of the FTC rule. It will argue that, according to the factors identified in Cort, a private right of action should be implied under the FTC rule.

\section{B. Implied Private Remedy Under Section 5 of the FTC Act: The Precedents}

Any argument that the FTC rule promulgated pursuant to section 5 of the Act impliedly creates a private right of action must first take account of Holloway v. Bristol-Myers Corp. ${ }^{110}$ In Holloway, the District of Columbia Circuit Court held that there is no implied private right of action under section 5 because Congress intended the administrative program of enforcement explicitly provided by the Act to be exclusive and because a private remedy would conflict with the legislative scheme. ${ }^{111}$ The

${ }^{109}$ Id. at 78 (citations omitted).

110485 F.2d 986 (D.C. Cir. 1973). Holloway was a consumer class action, with plaintiffs alleging as one ground of recovery that defendant Bristol-Myers' Excedrin advertisement, representing that its product Excedrin is and has been shown to be a more effective pain relieving agent than common aspirin, constituted a deceptive trade practice within the meaning of sections 5 and 12 of the Act. Id. at 987-88.

${ }^{11}$ Id. at 1002; accord, Carlson v. Coca-Cola Co., 483 F.2d 279 (9th Cir. 1973). The Holloway court gave only slight attention to the federalism issue, noting simply that "Congress has superimposed a structure of Federal law upon the existing system of common law remedies for fraud and deceit without preempting or superseding the latter." 485 F.2d at 989. Holloway has been criticized for underemphasizing the factor of especial benefit, which arguably is found in the strong policy of the Wheeler-Lea Amendments to protect consumers from unfair or deceptive commercial practices. See, 
court's finding of legislative intent to exclude private enforcement, based in part upon statutory construction and in part upon a reading of the legislative histories of the original Act of 1914 and the Wheeler-Lea Amendments of 1938, is open to criticism. ${ }^{112}$ The court reasoned as follows: The Supreme Court, in Moore ". New York Cotton Exchange, ${ }^{113}$ denied a private remedy under section 5 as worded prior to the 1938 Wheeler-Lea Amendments. The 1938 amendments, recognizing the need to protect consumers as well as injured competitors, endowed the FTC with new and more potent enforcement tools but did not explicitly overrule Moore by providing the additional enforcement mechanism of a private right of action. Thus, the Holloway court inferred that Congress intended agency enforcement to be exclusive. ${ }^{114}$

Several observations should be made concerning this inference of legislative intent. First, the precise nature of the holding in Moore is a subject of much debate; ${ }^{115}$ a more limited reading of the case would place primary, but not exclusive, jurisdiction in the FTC. ${ }^{116}$ Second, even granting the Holloway court's reading of Moore, making legislative silence-here Congress' failure to explicitly overrule the Moore interpretation-dispositive of legislative intent is a fallacious method of statutory construction. ${ }^{117}$ Third, the court's implicit assumption, founded upon the maxim expressio unius est exclusio alterius, ${ }^{118}$ that establishment of an elaborate scheme of agency enforcement indicates an intent to preclude other means of enforcement, specifically private ac-

Gard, Purpose and Promise Unfulfilled: A Different View of Private Enforcement Under the Federal Trade Commission Act, 70 Nw. U.L. Rev. 274, 285-91 (1975); Note, supra note 49, at 780; Note, Private Rights of Action Under the Federal Trade Commission Act, 11 Houston L. Rev. 699, 705 (1974). See also Guernsey v. Rich Plan, 408 F. Supp. 582, 588 (N.D. Ind. 1976).

${ }^{112}$ See, e.g., Guernsey v. Rich Plan, 408 F. Supp. 582, 588 (N.D. Ind. 1976); Note, supra note 49, at 780-85; Note, Divesting the FTC of Exclusive Enforcement of the Federal Trade Commission Act: Guernsey v. Rich Plan of the Midwest, 38 U. PITt. L. Rev. 113 (1976). See generally Implications, supra note 104, at 1411-26.

113270 U.S. 593 (1926).

114485 F.2d at $990-97$.

115 See, e.g., Guernsey v. Rich Plan, 408 F. Supp. 582, 588 (N.D. Ind. 1976); Note, supra note 49, at 782-83; Note, supra note 111, at 705. Because Moore predated the Wheeler-Lea Amendments, its relevance to the issue of consumers' rights under the Act is doubtful.

116270 U.S. 593, 603 (1926) ("This [action] is an attempt to allege unfair methods of competition, which may be put aside at once, since relief in such cases . . must be afforded in the first instance by the [FTC]."); see Guernsey v. Rich Plan, 408 F. Supp. 582, 588 (N.D. Ind. 1976).

${ }^{117}$ See, e.g., Note, supra note 49, at 783-85; Implications, supra note 104, at 1411-26.

${ }^{118}$ Expression of one thing is the exclusion of another. 
tions, is belied by several Supreme Court decisions. ${ }^{119}$ Fourth, the legislative history cited in Holloway is at most inconclusive regarding legislative intent either to create or to preclude a private remedy. ${ }^{120}$ Finally, the Cort decision arguably assigns legislative intent only a secondary role in the implication test ${ }^{121}$ and, if this reading of Cort is correct, absent a clear indication of intent to deny a private remedy there should be no presumption of the exclusivity of a statute's explicit enforcement mechanism. ${ }^{122}$ In short, implication of a private remedy should not be made contingent on an "extrapolation of legislative intent." ${ }^{23}$ Rather, given the implication doctrine's underlying rationale, ${ }^{124}$ it seems far more appropriate that the determinative factors be the necessity of a private remedy to protect the rights of those to be "especially benefitted" by the statute and the absence of significant conflict with other primary statutory policies.

${ }^{119}$ E.g., Allen v. State Bd. of Elections, 393 U.S. 544 (1969) (implied private remedy exists under the Voting Rights Act of 1965 despite the explicit remedy provided therein of enforcement by the Attorney General via civil suits); J.I. Case v. Borak, 377 U.S. 426 (1964) (private enforcement right implied under the Securities and Exchange Act of 1934 notwithstanding the SEC enforcement machinery explicitly provided therein). But see National R.R. Pass'rs Corp. v. National Ass'n of R.R. Pass'rs, 414 U.S. 453,458 (1974) (relying in part on the expressio unius maxim, the Court found no private right of action for violations of Rail Passengers Service Act of 1970 except in the limited circumstances specified in the Act); McMahon \& Rodos, supra note 104, at 191-92:

Although it may be foolhardy to predict the result of future suits seeking implication of private causes of action, the authors believe that ... with the Supreme Court as it exists today, if a statute provides for participation by an administrative agency and such participation in any way would effectuate the congressional purpose of the statute, the Court will not imply a private cause of action.

${ }^{120} \mathrm{See}$ sources cited at note 112 supra. There is legislative history that might be construed as supporting the inference that Congress did intend to create a private right of enforcement of the Act. See, Gard, supra note 111, at 288. But see Comment, Private Enforcement and Rulemaking under the Federal Trade Commission Act: Expansion of FTC Responsibility, 69 Nw. U.L. REv. 462, 471-72 (1974) (Only the legislative history of the 1914 Act is discussed; the conclusion is reached that, overall, this history "proves equivocal." Id. at 474. The author praises the Holloway decision).

${ }^{121}$ Discussing National R.R. Pass'rs Corp. v. National Ass'n of R.R. Pass'rs, 414 U.S. 543 , the Court suggested that only when the legislative history provides specific support for the proposition that remedies are to be exclusive and the provision under discussion creates a private cause of action for some plaintiffs for some kinds of disputes is the expressio unius maxim relevant. 422 U.S. at $82-83$ n.14. Thus, it is reasonable to infer that the legislative intent factor, as well as the expressio unius maxim, will be given a lesser role in implication cases than the other factors that are part of the implication analysis.

${ }_{122}$ See 422 U.S. at $82-83$ \& n.14. For a more detailed discussion of the Cort legislative intent factor, see Emerging Standards, supra note 105, at 310-11.

123422 U.S. at 83 n. 14.

${ }^{124}$ See text accompanying notes 105-06 supra. 
In light of the general rationale of the implication doctrine, then, the second major ground for the Holloway holding-that a private right of action would conflict significantly with the Act's explicit enforcement scheme ${ }^{125}$-is the more telling. The court in Holloway argued that the Act's enforcement policy is predicated upon the FTC's expertise both in giving specific content to section 5's broad proscription of "unfair or deceptive acts or practices in commerce" and in exercising discretion concerning when and how to prosecute violators. ${ }^{126}$ According to this argument, piecemeal private actions before an assortment of courts would jeopardize the development of coherent precedent construing the Act. Further, because motivated by individual concerns, such actions only rarely would coincide with the agency's prosecutorial strategy. ${ }^{127}$ However, even with private actions the FTC's expertise could be tapped-either by its intervention in those actions or, under the doctrine of primary jurisdiction, ${ }^{128}$ through referring to it for preliminary determination issues within its special competence. ${ }^{129}$ The Holloway court rejected these alternatives, however, because they arguably involved a reduction in the FTC's prosecutorial discretion. ${ }^{130}$ The court also rejected a final contention that since limited resources effectively prevented the FTC from proceeding against all but a very few violators, private actions, rather than interfering with the agency's enforcement program, were a necessary supplement to implementation of section 5's policy of consumer protection. ${ }^{131}$

125485 F.2d at $997-1002$.

${ }^{126}$ FTC expertise is repeatedly evoked in the opinion. $485 \mathrm{~F} .2 \mathrm{~d}$ at 990 , 995-96, 997, 998-99. See Note, supra note 49, at 785-88; Comment, supra note 120 , at 475 ("The FTC, with its over-view of the national economy, is in a better position than a private litigant to gauge the injury a deceptive practice will cause to the public and to balance this against the likely cost of eliminating the practice."). But see Guernsey v. Rich Plan, 408 F. Supp. 582 (N.D. Ind. 1976):

To conclude that without exception, the Federal Trade Commission . . . is in a better position than a private litigant to gauge the injury a deceptive practice will cause to the public . . . ignore[s] the basic premise of the free enterprise economy-that consumers should have the opportunity to choose between competing merchants on the basis of price, quality and service.

Id. at 588 .

${ }^{127} 485 \mathrm{~F} .2 \mathrm{~d}$ at $997-98$.

${ }^{128}$ See Note, supra note 49 , at 786.

${ }^{129}$ For example, whether a particular course of conduct constitutes a deceptive trade practice within the meaning of $\$ 5$ might be referred to the FTC for preliminary determination.

${ }^{130} 485$ F.2d at 999.

${ }^{131} \mathrm{Id}$. at 1000-02. The court stressed the impairment of FTC discretion that would result if private actions were allowed. J.I. Case v. Borak, 377 U.S. 426 (1964), which used a "necessary supplement" rationale to imply a private right of action under the 
The argument in Holloway that a private remedy is inconsistent with the legislative scheme is unpersuasive to the extent that it gives lesser weight to the importance of section 5's policy of protecting consumers than to the secondary policy of maintaining the integrity of the Act's enforcement mechanism. ${ }^{132} \mathrm{Al}-$ though both grounds of the decision, therefore, are vulnerable to attack, this Comment adopts the position that Holloway is good law when a private remedy is sought for an alleged violation of the bare, uninterpreted terms of section 5 . The case, however, is not an apt precedent for resolving the issue whether a private remedy should be implied to redress violations of section 5's terms as authoritatively construed by the FTC either in an adjudicative proceeding or in a trade regulation rule such as the preservation of defenses rule. ${ }^{133}$ When the FTC has already defined explicitly the range of acceptable trade practices in a particular area, the conflict between a private remedy and the statutory scheme of enforcement is significantly reduced, if not eliminated altogether. Coherence of precedent is assured, because the courts will grant relief only when the offending conduct already has been construed in the expert judgment of the FTC to be in violation of section $5 .{ }^{134}$ Private actions still will

Securities and Exchange Act of 1934, was distinguished on the ground that the jurisdictional provision involved in Borak was general, whereas those provisions in the Federal Trade Commission Act are specific. 485 F.2d at 1001 . The court also emphasized that in Borak, the SEC intervened as amicus, urging that private remedies be recognized. Id. Gard points out, however, that the FTC also has advocated private enforcement of the Act. Gard, supra note 111 , at $280,288-89$.

${ }^{132}$ See note 111 supra.

${ }^{133}$ This is the position taken in Guernsey v. Rich Plan, 408 F. Supp. 582, 587-89

(N.D. Ind. 1976); Note, supra note 49, at 789-90.

${ }^{134}$ See, e.g., Note, supra note 49 , at $789-90$.

In the situation under discussion here, the courts will not need the FTC's expert guidance to determine whether the rule has been violated. An alleged omission of the required notice from a consumer note or incorporation of a waiver of defense clause into an agreement of sale involves straightforward, nontechnical factual issues. In the case of omission of the notice from a consumer loan agreement, however, whether there has been a violation of the rule depends upon the factual determination of whether the loan is a "purchase money loan," and this turns on whether the creditor and seller are "affiliated . . by common control, contract, or business arrangement" or whether a "referral" has taken place within the meaning of the rule. See notes 60, 68-73 supra \& accompanying text. These can indeed be complex factual issues; concern in the business community regarding the exact reach of part (b) of the rule led the FTC to issue Enforcement Policy, supra note 11. See id. 34,595. Arguably, therefore, the interest articulated in Holloway of ensuring coherence of precedent under the Act might justify denying a private remedy in interlocking loan situations. The specter of each state jurisdiction formulating a different standard of what constitutes a "purchase money loan," or alternatively of the FTC having to intervene in numerous local contract disputes to guarantee the application of a uniform standard, might move the courts to 
impinge on FTC's prosecutorial discretion, but the need for this discretion relative to the need to protect individual consumers is diminished when the agency already has determined that the conduct violates the Act. ${ }^{135}$ Furthermore, in these instances, the FTC's failure to move against violators may well result from resource limitations and not from exercise of discretion. ${ }^{136}$ In the absence of a significant conflict with the enforcement policy of the Act, the dominant concern should be to effectuate the Act's policy of affording consumers adequate protection from deceptive trade practices.

Taking these considerations into account and distinguishing Holloway on its facts, in Guernsey v. Rich Plan ${ }^{137}$ the United States District Court for the Northern District of Indiana found an implied private right of action in a case involving alleged conduct that, in an earlier proceeding before the FTC, ${ }^{138}$ had been ruled to be in violation of section $5 .{ }^{139}$ Justifying its holding, the court noted:

[Assuming the allegations of the complaint to be true] Rich Plan of the Midwest... would fall within the class defined in the consent decree [issued in 1963]. As the activities of the companies involved in the consent

abstain from interfering in this area. The FTC, however, contemplates that different state jurisdictions will construe "purchase money loan" for purposes of any private remedies that may be created by state law: "This Statement is issued as guide for compliance with the Rule. It is also intended as an aid to assure consistent application of the Rule under those state laws which create additional private remedies for violation of its requirements." Id. (emphasis supplied). Given the FTC's apparent view that state courts can construe "purchase money loan" without doing violence to uniformity, therefore, courts should not eschew implication of a federal remedy in interlocking loan situations merely because of the difficult underlying factual determinations.

135 Note, supra note 49 , at $788-89$.

${ }^{136} I d$. at 792; see note 91 supra \& accompanying text.

137408 F. Supp. 582 (N.D. Ind. 1976), noted in 29 VAND. L. Rev. 1077 (1976).

${ }^{138}$ The prior proceeding was nonadjudicative in nature; that is, it did not involve a formal hearing before an administrative law judge. Although the consent decree that issued therefrom did not, therefore, formally establish that defendant's conduct violated $\S 5$, it is conclusive of the FTC's opinion in this regard. The argument that a private action premised on a prior FTC proceeding does not conflict with the agency's own enforcement of the Act would seem to be unaffected by whether the prior proceeding was formally adjudicative. But see 29 VAND. L. REv. 1077, 1085 (1976) ("[P]rivate enforcement may well cause a loss of whatever effectiveness the Commission now can claim in securing compliance with the Act through nonadjudicative proceedings because ... entering into a consent agreement with the FTC would seem tantamount to inviting a lawsuit." (footnote omitted)).

${ }^{139}$ Although merely distinguishing Holloway, the Guernsey court questioned both grounds of the Holloway decision along the lines suggested in text accompanying notes 112-31 supra. 408 F. Supp. at 586-88. Thus, even though the precise holding in Guernsey only distinguishes Holloway, its dicta suggest that Holloway be rejected altogether. 
decree above are nearly identical to the alleged activities of the defendant Rich Plan of the Midwest, it may be inferred that the Federal Trade Commission would have the same view of the practices in this case as it had of the practices that it ruled on in the 1963 cease and desist order. If that is the case, then, since the Federal Trade Commission has examined the complained of practices and found them wanting, one of the hurdles to the private enforcement of the Federal Trade Commission Act has been cleared . . . . ${ }^{140}$

It concluded: "The Federal Trade Commission Act has been the subject of 60 years of interpretation through adjudication and over ten years of rulemaking. . . . Both businessmen and courts should have no trouble determining the precise stricture of the act."141

Directly in conflict with Guernsey is Bott $v$. Holiday Universal, Inc. ${ }^{142}$ a recent decision of the United States District Court for the District of Columbia. In Bott, defendants' alleged violation of an FTC consent order was held to be an insufficient basis to distinguish Holloway. The court followed Holloway in dismissing the complaint "not only because it is the law of this Circuit, but also because it is the correct decision." 143 To support its assertion that Holloway was correctly decided, the court merely quoted the passage from Holloway stating that a private right of action necessarily would conflict with the Act's policy of placing the enforcement decision within "the FTC's sound discretion and expert judgment."144 The court did not explain why the policy favoring enforcement discretion should outweigh the substantive policy to be enforced-protection of consumers-when the agency has identified specifically the prohibited conduct. ${ }^{145}$

140408 F. Supp. at 587-88.

${ }^{141} I d$. at 588 (citation omitted).

${ }^{142}$ Civ. No. 75-1982 (D.D.C. July 14, 1976).

${ }^{143} I d$. at 3. 1973)).

${ }^{144}$ Id. (quoting Holloway v. Bristol-Myers Corp., 485 F.2d 986, 997-98 (D.C. Cir.

${ }_{145}$ At least one commentator shares the view of the Bott court:

Limiting the implied private right of action to cases in which the FTC has ruled on the practices involved ... recognized that the FTC's expert judgment and inherent agency discretion in defining "unfair or deceptive acts or practices" are central to the statutory framework. ... [T] The Commission's expertise and discretion are no less applicable to the exercise of its enforcement powers: the statutory scheme clearly comprehends that administrative flexibility will be brought to bear both in defining violations and in dealing with violators. With the FTC's flexibility in the latter regard, equally central to the FTCA, even 
Guernsey was summarily disposed of as "contrary to the legislative history and intent of the FTC Act and subsequent amendments, as examined in the Holloway decision."146

The Bott court ignored the possibility that Holloway's argument against private enforcement, based on legislative history and inferred congressional intent, may have been weakened substantially by Cort. ${ }^{147}$ It also failed to recognize that the policy justifications for denying a private remedy in Holloway should not necessarily bar such a remedy on the very different facts of Bott or Guernsey. ${ }^{148}$ When private rights of action are sought, courts should distinguish cases in which the bare terms of section 5 are at issue from those in which previously articulated standards of the FTC form the basis of the complaint. In the latter situations, courts should find implied private rights of action so long as such remedies would conform to the Cort criteria. This Comment will show that an implied private remedy under the FTC rule preserving claims and defenses does conform to those criteria. ${ }^{149}$ Given the peculiar procedural posture in which consumers are likely to find themselves when they wish to call on the aid of the rule, reliance on agency enforcement will be a wholly inadequate remedy; implication of a private remedy, therefore, is appropriate to assure vindication of section 5 policy as embodied in the rule.

\section{Implied Private Remedy Under the FTC Rule}

\section{Unique Procedural Posture}

Returning once again to the introductory scenario, if the FTC rule were in force at the time of the transaction between Seller and Consumer, when the credit contract was signed, Consumer may have been unaware that it omitted a notice required by federal law. When Financer, seeking unpaid installments, claims the holder-in-due-course privilege against Consumer in

limited private enforcement is inconsistent.

29 VAND. L. REv. 1077, 1085 (1976).

${ }^{146}$ Civ. No. 75-1982, slip op. at 3 (D.D.C. July 14, 1976).

147 See notes 121-23 supra \& accompanying text.

${ }^{148}$ In order to effectuate a primary statutory policy, the Supreme Court has implied a private cause of action under a statute that it had previously construed to exclude such a remedy when presented with a new fact situation in which the conflict that dictated the earlier holding no longer obtained. Compare Hewitt-Robins, Inc. v. Eastern Freight-Ways, Inc., 371 U.S. 84 (1962), with T.I.M.E. Inc. v. United States, 359 U.S. 464 (1959). For further discussion of these two cases, see, e.g., Implications, supra note 104, at 1427-28.

${ }^{149}$ Text accompanying notes 159-213 infra. 
state court, however, Consumer's counsel should be cognizant of the rule as a potential source of a federal right to assert Consumer's defense, be it nondelivery, breach of warranty, or other personal defense. ${ }^{150}$ Applying the doctrine of implication in this procedural posture presents two unique aspects: (1) the federal issue is raised in the context of a state adjudication, and (2) the implied private right of enforcement claimed is not the right to bring suit for reformation of the contract, but rather the right to raise underlying defenses that the omitted clause would have preserved for Consumer. A more characteristic posture for applying the implication doctrine-a suit for affirmative relief in federal court-would result if Consumer sued Seller in federal district court for reformation of the credit contract to include the notice required by the FTC rule. Whether, as a practical matter, such a suit would ever be brought is contingent upon Consumer's learning, soon after signing the negotiable note over to Seller, of the FTC rule and its significance. ${ }^{151}$

The two distinctive elements enumerated above should not constitute a basis for declining to apply the implication doctrine. State courts are bound by the Supremacy Clause ${ }^{152}$ to adjudicate the merits of federal questions in cases otherwise within their jurisdiction. ${ }^{153}$ Further, assertion of an implied private federal right defensively rather than offensively should not affect recognition of the underlying substantive right. An implied federal right to assert defenses against Financer by its very nature often will be asserted in a defensive posture; ${ }^{154}$ Consumer, refusing a claim for payment, can only assert his implied right defensively. ${ }^{155}$ Moreover, Consumer's defensive assertion of his im-

150 When an earlier version of the rule was under consideration by the FTC in 1971-73, the issue of the rule as a potential source of federal rights was discussed in legal commentary. See Comment, supra note 49, at 184-86; Note, The FTC Proposed Rule and the Holder in Due Course, 18 S.D. L. REv. 516 (1973).

${ }^{151}$ A third posture could arise as follows: After Consumer has made a downpayment to Seller and installment payments to Financer, Seller breaches the sales agreement. Consumer then might sue either Seller or Financer in federal court to recoup the sums paid, grounding the action in the FTC rule. For a discussion of implied consumer rights as against the financer, see text accompanying notes 186-200 infra. This Comment will not explore the ramifications of affirmative use of the rule by consumers because, realistically, consumers most often will be caught in the defensive posture; it is in such a posture that the consumer's need for a private remedy is greatest. See text accompanying notes 85-93 supra.

${ }^{152}$ U.S. ConsT. art. VI, cl. 2.

${ }^{153}$ Mondou v. New York, N.H. \& H.R.R., 223 U.S. 1 (1912).

${ }^{154} \mathrm{~A}$ consumer may wish to assert his defense on an underlying sales contract for goods offensively against a financer seeking to repossess the goods. See note 2, supra.

${ }^{155}$ Of course, if the implied right to preserve claims against the holder of a credit contract permits a consumer to sue affirmatively on those claims against such a holder, 
plied right is only a matter of form, not of substance; a successful action for reformation of the contract to include the clause preserving his claims and defenses automatically would permit Consumer to assert those claims and defenses in state court. ${ }^{156}$ The question whether the rule yields an implied private right of enforcement ${ }^{157}$ to Consumer, therefore, turns not on the procedural issue, but on the conformity of such an implied right to the Cort criteria. ${ }^{158}$

\section{Application of the Cort Test}

\section{a. Especial Benefit}

As mentioned earlier, the Holloway decision underplayed the strong policy of the Wheeler-Lea Amendments in favor of protecting consumers from deceptive trade practices. ${ }^{159}$ It might be argued that although the Wheeler-Lea Amendments evidenced a general policy favoring consumers, the scheme of the Act entrusted the FTC with the responsibility of singling out the classes of consumers to be especially benefited. In other words, as the Holloway opinion repeatedly stressed, the Act assigns to the regulatory agency and not to the courts the function of particularizing the Act's general mandate. ${ }^{160}$ This objection is totally inapposite to the case now under consideration; in promulgating its rule, the FTC clearly singled out a situation such as that of the introductory scenario as meriting special concern and as one of the very problems to be remedied:

In announcing this rule, we are pursuing our statutory mandate to identify and prevent unfair or de-

that opportunity for an affirmative suit should not bar the consumer from counterclaiming for past payments if it is the holder who brings suit.

${ }^{156}$ The FTC is not limited to seeking mere reformation of consumer credit contracts, but may also seek damages on behalf of consumers suffering injury resulting from failure to include the required notice, see note 56 supra \& accompanying text -injury that would arise only if the consumer has an underlying defense or claim. An implied private consumer action against a financer for damages resulting from the omission of the clause would parallel the FTC's right of action against the seller to seek the same damages on the consumer's behalf.

157 Private rights of action may be implied under regulations of federal agencies. See, e.g., J.I. Case Co. v. Borak, 377 U.S. 426 (1964) (finding a private cause of action under Rule 14a-9, 17 C.F.R. $\$ 240.14 a-9$ (1975) promulgated pursuant to $\S 14$ (a) of the Securities and Exchange Act of 1934, 15 U.S.C. $\$ 78 \mathrm{n}$ (a) (1970)); Kardon v. National Gypsum Co., 69 F. Supp. 512 (E.D. Pa. 1946) (finding a private cause of action under Rule 10b-5, 17 C.F.R. 240.10b-5 promulgated pursuant to $\S 10(\mathrm{~b})$ of the Securities and Exchange Act of 1934, 15 U.S.C. $\$ 78 \mathrm{j}(\mathrm{b})(1970))$.

${ }^{158}$ See text accompanying note 109 supra.

${ }^{159}$ See notes 46-49, 111-24 supra \& accompanying text.

${ }^{160}$ See note 126 supra. 
ceptive practices in the marketplace. . . . We conclude that a consumer's duty to pay for goods or services must not be separated from a seller's duty to perform as promised, regardless of the manner in which payment is made. In reaching this conclusion we note thousands of instances, documented in the record of this proceeding, where the separation of what are normally regarded as reciprocal duties caused substantial injury to consumers. The common sense shock articulated by many of the consumer witnesses upon learning that their duty to repay a creditor was totally unrelated to their seller's promises is perhaps the clearest and most direct evidence of the injurious and distorted impact of the challenged practices. ${ }^{161}$

\section{b. Intent to Deny a Private Remedy}

Regarding the legislative intent prong of the Cort test, the Supreme Court noted: "[I]n situations in which it is clear that federal law has granted a class of persons certain rights, it is not necessary to show an intention to create a private cause of action, although an explicit purpose to deny such cause of action would be controlling."162 Because the rule's specific purpose is to preserve consumers' rights to raise claims and defenses, it is not necessary to demonstrate an intention to create a private remedy but only to show a lack of explicit intent to deny one.

The current rule and its proposed revision are silent on the issue of consumers' remedies when the required notice is omitted from the credit contract. ${ }^{163}$ Following the Holloway court, financers could argue that, applying the maxim expressio unius est exclusio alterius, the inference must be drawn that the FTC was granted an exclusive right to enforce the Act and all pursuant agency regulations. The Act's failure to create expressly a private right of enforcement, however, hardly demonstrates that Congress intended the FTC's enforcement of such regulations to be exclusive. ${ }^{164}$ Because consumer redress action brought by the FTC would be an inadequate, after-thefact remedy, ${ }^{165}$ it would be improper to infer congressional in-

161 FTC Statement, supra note 11 , at 53,523 (footnote omitted).

162422 U.S. at 82 (emphasis in original).

${ }^{163}$ See note 99 supra \& accompanying text.

${ }^{164}$ Defendants in Guernsey v. Rich Plan, 408 F. Supp. 582 (N.D. Ind. 1976), unsuccessfully made this argument in the interlocutory appeal to the Seventh Circuit. Brief for Appellant at 12-15.

${ }^{165}$ See Gard, supra note 111 , at $290-91$ n.87; note 38 supra \& accompanying text. 
tent to preclude a private consumer remedy from the grant of authority to the FTG to engage in consumer redress litigation. When Congress has not explicitly restricted the scope of available remedies, courts should not attribute to it an intent to limit that scope such that only inadequate remedies are available. The Supreme Court has sharply criticized and implicitly rejected such an application of expressio unius est exclusio alterius. ${ }^{166}$ Furthermore, although during the period 1969 to 1971 several bills that explicitly provided for private enforcement of the Act either died in committee or were never brought to a floor vote before adjournment, ${ }^{167}$ the failure of these bills to become law then sheds no light on congressional intent regarding private remedies four to six years later. ${ }^{168}$ Whatever congressional silence may be, it is not intent to deny a private remedy sufficiently explicit to circumvent the intent prong of Cort's implication test. ${ }^{169}$

\section{c. Consistency with the Legislative Scheme}

In Holloway, the fatal argument to implication of a private right of enforcement was the one suggesting that interference with the FTC's prosecutorial discretion would unnecessarily conflict with the general enforcement scheme of the Act. ${ }^{170}$ The preservation of defenses rule, constituting the concrete expression of the FTC's expert opinion concerning the balance of equities to be struck in applying section 5's broad proscription to the facts of the introductory scenario, distinguishes cases governed by the FTC rule from Holloway; the importance of prosecutorial discretion is diminished once the agency has particularized its general mandate by specifying certain conduct as violative of the statute. ${ }^{171}$ Concededly, affording a private con-

166 See cases cited at note 119 supra.

167 See note 57 supra.

${ }^{168}$ At the same time that Congress strengthened the FTC's remedial tools, it passed the Magnuson-Moss Warranty Act, 15 U.S.C. $\$ \S 2301-2312$ (Supp. V 1975), as Title I of the 1975 Act.

The Magnuson-Moss Warranty Act established minimum disclosure standards for written warranties in consumer sales. Id. $\S 2304$. Congress provided injured consumers with a private cause of action for violations of the warranty provisions contained in Title I. Id. $\$ 2310$ (d). That Congress did not provide a private cause of action for violations of FTC trade regulations-the authority for which was provided in Title II of the $1975 \mathrm{Act}$, see note 53 supra-is not, however, grounds for inferring a congressional intent to deny a private cause of action under the latter Title. See, Cort v. Ash, 422 U.S. 66,82 n. 14 (1975); Emerging Standards, supra note 104, at 311.

${ }^{169}$ See text accompanying note 162 supra.

${ }^{170}$ See 485 F.2d at 997-1002; text accompanying notes 125-26 supra.

${ }^{171}$ See notes 132-36 supra and accompanying text. 
sumer remedy does invade the FTC's prosecutorial discretion to the extent that a private suit or assertion of defenses pre-empts the agency's determination of whether to bring a consumer redress action at a later date on the same consumers' behalf. Yet one might question the legitimacy of preserving that discretion when the cost is cutting consumers off from their defenses and forcing them to shoulder the immediate burden of payment-a result in direct conflict with the policy articulated by the FTC in its rule.

J.I. Case Co. v. Borak ${ }^{\mathbf{1 7 2}}$ is instructive in this regard. The plaintiff in that case claimed an implied private right to enforce rule $14 \mathrm{a}-9^{173}$ of the Securities and Exchange Commission (SEC), promulgated under section 14(a) of the Securities and Exchange Act of $1934,{ }^{174}$ which prohibits the use of false or misleading proxy statements. In holding that a private right of enforcement existed, the Supreme Court found such a private right compatible with the statutory scheme of agency enforcement and noted that "[p]rivate enforcement of the proxy rules provides a necessary supplement to Commission action." 175 The Court further commented that the SEC had insufficient resources to enforce thoroughly the proxy rules ${ }^{\mathbf{1 7 6}}$ - a situation likely to confront the FTC in its efforts to enforce its trade regulation rules. ${ }^{177} \mathrm{~A}$ private right of enforcement, therefore, does not conflict materially with the Act's explicit scheme of agency enforcement and fairly may be said to enhance enforcement of the rule.

It remains to be established that implication of a private consumer remedy, notwithstanding the omission from the credit contract of the notice to holders prescribed by the rule, does not significantly conflict with primary policies of the agency regulation. Two policies of the rule with which an implied private right of enforcement could conflict might be alleged: a policy conditioning consumers' right to raise their defenses on inclusion of the notice to holders in the credit contract and a policy making the rule enforceable only against sellers. The status of these policies as true objectives of the rule, however, is highly questionable.

Regarding the first policy, whether the rule can be said to

172 J.I. Case Co. v. Borak, 377 U.S. 426 (1964).

17317 C.F.R. $\$ 240.14 a-9$ (1976).

17415 U.S.C. \& 78n(a) (1970).

175377 U.S. at 432.

${ }^{176} I d$.

${ }^{177}$ See note 91 supra \& accompanying text. 
condition consumers' right to raise defenses on the inclusion of the notice to holders in the credit instrument hinges on what is taken to be the purpose of that notice. The purpose could be: (1) to give actual notice to third-party financers so that they will not be deprived "innocently" of their holder-in-due-course status, (2) to impose an external form on the consumer credit instrument such that state courts will declare it to be nonnegotiable, or (3) to give consumers notice of their right to raise claims and defenses against third-party financers who purport to be holders in due course. If the required notice is designed to provide actual notice to third-party financers, then omission of the notice, it might be argued, should allow the financer to assert holder-in-due-course status. One rationale for shifting the risk of seller misconduct from the consumer maker of the instrument to the third-party financer is the latter's superior ability to prevent and police such misconduct. ${ }^{178}$ This rationale is based on the assumption that the financer has "notice" of his obligation to police the seller. Even if lack of actual notice precludes the financer from policing the seller's conduct before the fact, however, the financer still has access to such weapons as "repurchase" provisions that may be utilized against the seller after the fact. In any event, the creditor always has the ability, which consumers lack, to spread the risk of loss. Thus, even were the purpose of the notice to holders to provide actual notice to financers, the balance should still be struck in favor of not conditioning consumers' rights to raise defenses on inclusion of the notice. ${ }^{179}$ In promulgating the rule, however, the FTC gave no indication that the requirement of incorporating the notice to holders in the credit instrument had any purpose beyond foreclosing courts from construing the instrument to be negotiable. ${ }^{180}$ Importantly, the notice to holders required by the FTC really does not give the kind of actual notice that traditionally defeats holder-in-due-course status at state law-actual notice of a particular claim or defense. ${ }^{181}$ Rather it gives notice that financers closely dealing on a continuing basis with sellers in consumer credit transactions no longer will be accorded protected status. Notice of this character need only be given once-financers hardly can argue that they need a separate reminder of this basic shifting of risk in each new con-

${ }^{178}$ See notes 79-81 supra \& accompanying text.

179 Examples of state statutes providing that consumer defenses are to be preserved even against a holder in due course are cited at note 99 supra.

${ }^{180}$ See FTC Statement, supra note 11, at 53,522-25.

${ }^{181}$ See note 18 supra \& accompanying text. 
sumer contract. ${ }^{182}$ Sufficient notice of the altered balance of power in consumer credit-sale transactions is afforded by the FTC rule itself. Although inclusion of the notice is, therefore, unnecessary for the purpose of alerting creditors who may be charged with constructive notice of the rule, inclusion may serve the purpose of informing consumers of their right to raise claims and defenses. ${ }^{183}$ Admittedly, many consumers may be ignorant of the legal significance of the notice, but for those who understand it, the notice may provide a valuable warning that they need not forego their defenses upon demand of payment from a third-party financer. Of course, if inclusion of the notice has as its purpose informing consumers of their rights, then omission should not be an excuse for divesting them of these rights should they learn about them from some other quarter, such as counsel.

The second inquiry is whether the rule evidences a policy that it be enforced only against sellers; if it does, an implied consumer right to raise defenses against financers should be denied. Under the proposed amendment to the current rule, this is a moot issue-both sellers and financers would be subject to its sanction. ${ }^{184}$ Even under the current rule, however, assertion of an implied right against financers, far from being contrary to the policy of the rule, would further its policy of preventing the separation of a consumer's duty to pay for goods from the seller's duty to fulfill contractual obligations. ${ }^{185}$

Harmony of an implied private right of action with the Act's enforcement scheme and the rule's policy, however, does not settle the issue. There remains the further question whether courts will extend the implication doctrine to encompass a third party. Generally, an implied right of action is asserted by a private litigant against a party who is the object of the statutory, regulatory, or constitutional duty. ${ }^{186}$ When violation of that duty causes injury to a person with an implied right of action, the

182 The realities of these transactions are such that financers always will know they are dealing with consumer contracts. When a consumer completes a negotiable note in conjunction with an installment sale, the note is usually attached by perforation to the agreement of sale. When the note is assigned by the seller the agreement of sale is transferred along with it to the financer-assignee. Furthermore, assignments generally are not made on an individual basis-a financer usually will purchase at discount large amounts of consumer paper issued by a particular seller. In the case of an interlocking loan, the financer will have to call the seller to arrange security.

${ }_{183}$ See FTC Statement, supra note 11, at 53,526.

184 See notes $94-95$ supra \& accompanying text.

${ }^{185}$ See notes 198-200 infra \& accompanying text.

${ }^{186} \mathrm{See}$ cases and sources cited at 104 supra. 
private litigant may seek redress against the violator. Thus, the Supreme Court held in Borak that stockholders have an implied right to sue a corporate director for violation of the SEC's proxy rules. ${ }^{187}$ Unlike the traditional implied federal right of action configuration, however, in the consumer's situation, although the duty imposed by the rule is violated by the seller, the consumer's injury-loss of defenses and claims against the holder of his credit contract-is caused by a third party outside the scope of the rule: the financer. The consumer's posture is further distinguished from that of the traditional private litigant when, as often will be the case, the consumer is in a defensive position. ${ }^{188}$ If consumers are denied an implied right of action against financers, they first must bear the loss resulting from the sellers' breach of duty and then seek damages from the sellers, paralleling the current process by which a consumer's claims and defenses are vindicated by the FTC. ${ }^{189}$ Assertion of an implied right of action-offensively or defensively-should be permitted against a third party who causes the actual injury as a result of the breach of duty that the regulation imposes on another. ${ }^{190} \mathrm{~A}$ consumer credit transaction such as the one set forth in the introductory scenario requires according the consumer an implied right to raise defenses against the financer that otherwise could be raised against the seller; if assertion of an implied right against such a third party is denied, any implied right of enforcement would be rendered largely ineffective and implementation of the policies underlying the rule would be inhibited. ${ }^{191}$ Although the implication doctrine generally has not been

187377 U.S. 426, $431-33$ (1964); see text accompanying notes 172-76 supra.

${ }^{188}$ See text accompanying notes 85-93, 150-51 supra. A consumer will not always be in a defensive posture; he may seek to sue either his seller or his financer for reformation of the contract or for damages. See note 151 supra \& accompanying text.

${ }^{189}$ See text accompanying note 93 supra. As a further complication, the seller may be judgment proof. See note 4 supra.

${ }^{190} C f$. Deckert v. Independence Corp., 311 U.S. 282 (1940) (when circumstances make recovery from a fraudulent seller of securities unusually difficult, a statutorily granted private cause of action against such sellers implies a right to seek equitable relief against a third-party insurance company that, in its capacity as administrator of a trust of common stocks, receives installment payments for shares and collects dividends and profits). In extending the statutorily created right of action to the third party, the Court noted that insofar as the courts have the power to enforce legal obligations

[t] he power to enforce implies the power to make effective the right of recovery

[that the obligation imposes]. And the power to make the right of recovery effective implies the power to utilize any of the procedures or actions normally available to the litigant according to the exigencies of the particular case.

$I d$. at 288 (emphasis in original).

191 See notes 198-200 infra \& accompanying text. 
extended to encompass such third parties, the basic principles underlying the implication cases do not conflict with such an extension. In Texas $\xi^{3}$ Pacific Railway v. Rigsby, ${ }^{192}$ stating that an appropriate plaintiff ${ }^{\mathbf{1 9 3}}$ may assert an implied right of action against a party defaulting on his statutory duty, ${ }^{194}$ the Court added, "So, in every case, where a statute enacts, or prohibits a thing for the benefit of a person, he shall have a remedy upon the same statute for the thing enacted for his advantage, or for the recompense of a wrong done to him contrary to the said law." "195 Similarly, in Borak the Court noted:

It is for the federal courts "to adjust their remedies, so as to grant the necessary relief" where federally secured rights are invaded. "And it is well settled that where legal rights have been invaded, and a federal statute provides for a general right to sue for such invasion, federal courts may use any available remedy to make good the wrong done."196

\section{The Borak Court also pointed out:}

"When a federal statute condemns an act as unlawful, the extent and nature of the legal consequences of the condemnation, though left by the statute to judicial determination, are nevertheless federal questions, the answers to which are to be derived from the statute and the federal policy which it has adopted." ${ }^{197}$

Insofar as the federal policy underlying the FTC rule is preventing the separation of a consumer's duty to pay from the seller's duty to fulfill contractual obligations, ${ }^{198}$ the policy can be effectuated fully only by permitting an implied right of action against the financer; by proposing its revised rule, ${ }^{199}$ the FTC acknowledged that full policy implementation requires bringing the financer within the scope of remedial action. Heeding the

192241 U.S. 33 (1916).

${ }^{193}$ One "for whose especial benefit the statute was enacted. . . ." Id. at 39.

${ }^{194}$ Id.

${ }^{195}$ Id. (citation omitted) (quoting Anonymous, 87 Eng. Rep. 791 (Q.B. 1706).

196377 U.S. 426, 433 (1964) (quoting Bell v. Hood, 327 U.S. 678, 684 (1946)).

197377 U.S. at 433 (quoting Sole Elec. Co. v. Jefferson Elec. Co., 317 U.S. 173, 176 (1942)). A state court may resolve the question of an implied federal right of action and permit the consumer to assert his defenses and claims against a third party. See text accompanying note 153 supra.

${ }^{198}$ Text accompanying note 61 supra.

${ }^{199}$ See notes $94-95$ and accompanying text. 
Borak Court's admonition that "it is the duty of the courts to be alert to provide such remedies as are necessary to make effective the congressional purpose," ${ }^{200}$ courts should permit assertion of claims and defenses against the financer, notwithstanding that the breach of duty under the current rule is by the seller. In no other way can the courts "make good the wrong done"201 to the consumer by violation of the FTC rule.

\section{d. Federalism Concerns}

Cort cited with approval ${ }^{202}$ the implication of a federal private right of action to enforce the SEC's proxy rules in J.I. Case Co. v. Borak. ${ }^{203}$ The Cort opinion recognized that it was entirely appropriate to afford the Borak plaintiff a federal remedy: "In Borak, the statute involved was clearly an intrusion of federal law into the internal affairs of corporations; to the extent that state law differed or impeded suit, the congressional intent could be compromised in state-created causes of action."204 By contrast, the plaintiff in Cort claimed an implied right to enforce the federal criminal statute prohibiting corporations from making "a contribution or expenditure in connection with any election at which Presidential and Vice Presidential electors ... are to be voted for."205 Plaintiff owned stock in a corporation that allegedly had made expenditures in connection with the 1972 presidential election. ${ }^{206}$ The Court noted that the purpose of the criminal statute was to eliminate undue corporate financial influence in elections and that protection of stockholders was, at best, a secondary concern. ${ }^{207}$ The Court held that it was appropriate, given the subsidiary nature of this policy to protect shareholders, to relegate plaintiff to state law remedies-ultra vires actions and actions for breach of fiduciary duty. ${ }^{208}$

Application of the federalism prong of the implication test involves, in effect, a determination of whether the consumer's case is more appropriately analogized to Borak or Cort. The FTC rule clearly is an intrusion of federal law into an area typically

200377 U.S. at 433 .

201 J.I. Case v. Borak, 377 U.S. at 433 (quoting Bell v. Hood, 327 U.S. 678, 684

(1946)); see text accompanying note 196 supra.

202422 U.S. at 85.

203377 U.S. 426 (1964); see text accompanying notes 172-76 supra.

204422 U.S. at 85.

20518 U.S.C. $\$ 610$ (1970).

206422 U.S. at 71.

${ }^{207}$ Id. at 80-82.

${ }^{208} \mathrm{Id}$. at 84 . 
regulated by state law; it is not less so merely because the rule is implemented through the mechanism of state law when the required notice is included in a consumer credit contract. ${ }^{209}$ Indeed, in promulgating its rule, the FTC intended to superimpose a uniform federal policy of preserving consumer defenses on the existing patchwork of state regulation of negotiability in consumer credit sales. ${ }^{210}$ The Borak Court noted that if state law "happened to attach no responsibility to the use of misleading proxy statements, the whole purpose of the section [of the Securities and Exchange Act] might be frustrated." ${ }^{11}$ Similarly, if state law did not permit assertion of claims and defenses against a financer, the purpose of the FTC rule-protection of consumers ${ }^{212}$-would be frustrated. The need for uniform, nationwide enforcement of a federal policy is strong justification for implying a federal remedy. ${ }^{213}$ Thus, Borak, not Cort, is the governing precedent on the federalism issue in the consumer situation and suggests that consumers should be accorded an implied federal right to assert claims and defenses-offensively or defensively-against third-party financers.

\section{IMPACT OF THE FTC RULE ON State Law Remedies}

A consumer who does not prevail on the issue of an implied federal right to raise claims and defenses still may argue for a remedy at state law. Of course, in jurisdictions that have ban-

${ }^{209}$ Text accompanying note 64 supra.

210 See FTC Statement, supra note 11, at 53,521. For a discussion of state regulation, see notes $28-44$ supra \& accompanying text.

211377 U.S. at $434-35$.

212 Note 161 supra \& accompanying text. Implication of a private remedy under the rule raises the issue of the FTC's power to preempt state law via its rulemaking power. Technically the preemption issue is not raised by the explicit operation of the rule. Even though inclusion of the notice to holders is a requirement of federal law, this requirement of itself does not displace state law-no state forbids the inclusion of a notice in credit instruments that renders them nonnegotiable. Once the notice is included, preservation of defenses results purely as a matter of state law. Note 64 supra \& accompanying text. If, however, when the notice to holders is omitted from the credit contract the FTC rule nonetheless impliedly permits preservation of claims and defenses, then the state law that otherwise would extend protected status to the holder is preempted. Although the FTC lacks the power to preempt effective state consumer protection regulation by its rulemaking, FTC preemption of ineffective state regulation by the rulemaking process is permissible. See H.R. REP. No. 1606, 93d Cong., 2d Sess. 45 (1974). State regulation of defense cut-off devices is plainly ineffective. See notes 28-44 supra \& accompanying text. For a fuller discussion of the preemption issue, see Verkuil, Preemption of State Law by the Federal Trade Commission, 1976 Duke L.J. 225.

${ }^{213}$ Emerging Standards, supra note 104, at 316; Implications, supra note 104, at 1436. 
ished negotiability from consumer credit sales, a consumer's right to raise claims and defenses is well established as a matter of state law. ${ }^{214}$ In other jurisdictions, depending upon whether the cut-off mechanism employed is a negotiable instrument or a waiver of defense clause, the right may also be explicit at state law. ${ }^{215}$ If, however, the consumer is the victim of an interlocking loan cut-off, then there is less likelihood of an explicit state law remedy. ${ }^{216}$ Where neither statute nor judicial precedent creates an adequate basis for remedy, one might argue that even when the notice to holders is not incorporated into a credit contract, financers should be charged with constructive notice of consumer claims and defenses by virtue of the rule and so denied holder-in-due-course status. ${ }^{217}$ Alternatively, it could be argued that notice of the rule strips financers of the good faith requisite to holder-in-due-course status under state law. ${ }^{218}$

Most courts, however, still adhere to a subjective test of good faith. ${ }^{219}$ To withhold protected status, one ordinarily must show actual knowledge, or reason to know, of a particular defense, not merely knowledge that some defense potentially may be raised. ${ }^{220}$ Furthermore, a holder has no duty of inquiry. ${ }^{221}$ The "close connectedness" doctrine represents a step in the direction of an objective standard of good faith, but it has been construed narrowly. ${ }^{222}$

Clearly, what a financer has notice of by virtue of the rule is not a consumer's particular defense but the federal policy judgment that, because financers are better able to avoid or spread the costs of sellers' misconduct, a consumer's right to raise a defense should be preserved. ${ }^{223}$ Such notice, therefore, may be held not to block holder-in-due-course status. Nor would a state court necessarily construe notice of the rule to render a financer lacking in the good faith requisite to holder-in-due-course status, even though the financer knowingly is contravening a federal policy by cutting the consumer off from claims and defenses. The state court very well may perceive state policy to strike a

${ }^{214}$ See notes $39-43$ supra \& accompanying text.

${ }^{215}$ See id.

216 See id.

${ }^{217}$ See Comment, supra note 49, at 183-84; text accompanying notes 77-78 supra.

${ }^{218}$ See Comment, supra note 49, at 183-84.

219 Littlefield, supra note 6.

${ }^{220}$ See id. at 65; Comment, supra note 49, at 183.

221 Comment, supra note 49, at 183.

${ }^{222}$ See notes 30-38 supra \& accompanying text.

${ }^{223}$ See notes $179-82$ supra \& accompanying text. 
different balance regarding the allocation of risk among consumers, sellers, and creditors. Denial of an implied federal remedy would constitute, in effect, a determination that federal policy does not override conflicting state policy for purposes of the financer's suit. For example, most state courts and legislatures have not found a referral relationship between a seller and a financer to be a sufficiently close connection to warrant denying a financer-assignee of a consumer note, much less a financerissuer of an interlocking loan, protected status. ${ }^{24}$ The state policy judgment may be that the financer, notwithstanding the referral relationship with the seller, is too "innocent" to be subjected to consumer defenses and that the availability of credit would be affected too adversely, to the detriment of consumers as a whole, by shifting the risk of a seller's misconduct onto the financer under these circumstances. Assuming, then, that a state court were not compelled to adopt the federal policy stance expressed in the FTC rule and to imply a right to raise defenses as a matter of federal law, it might not adopt voluntarily the federal standard.

\section{Conclusion}

In promulgating its rule, the FTC interpreted the Act's broad policy in favor of consumer protection to specifically subsume a policy of preserving consumer claims and defenses. Existing state law is inadequate to accomplish this purpose when the required notice to holders is omitted from the consumer credit contract; there is no uniformity among jurisdictions in regulation of negotiability in consumer transactions. If state law governs when the required notice has been omitted, therefore, the rule's clear standard will be sacrificed to the caprice of geographical location. Furthermore, in those jurisdictions that do regulate cut-off practices, consistent limitations generally are not placed on all three of the cut-off mechanisms. The most dramatic loophole in almost all jurisdictions is the failure to police interlocking loan transactions. Although state courts may adopt voluntarily the standard of the rule as a matter of state law, considerations of state policy well may foreclose such a result.

The policy of preserving consumer defenses cannot be enforced adequately by sole reliance on the mechanism explicitly provided by the Act-cease and desist proceedings and civil actions for consumer redress brought by the FTC. When a third- 
party financer demands payment from a consumer on a credit contract omitting the required notice to holders, the only remedy even potentially available is the FTC's civil action against the seller. Unless the seller is a large offender, however, such action is unlikely to be brought; even when it is, it takes place only after the consumer has made the demanded payments to the financer. A consumer might take independent action against the seller for breach of the underlying sales contract if sufficient resources were available-an unlikely possibility in the case of a poor consumer-but in the paradigm situation involving a small, judgment-proof seller, an action brought by the consumer, as by the FTC, would be fruitless. If the proposed revision is put into effect, the FTC would have the alternative of bringing redress action against the financer, but once again the likelihood of the agency exercising this option is small. In all cases the relief would come only after the consumer has paid the financer in the first instance-by no means an insignificant burden.

The preferred course should be for the courts to imply a private federal right under the rule, permitting the consumer to raise claims and defenses against the financer notwithstanding omission of the notice. Objections leveled against implication of a private right of enforcement do not apply in these circumstances. The expert opinion of the FTC on the subject of defense cut-off practices in consumer credit-sale transactions has been given concrete expression in the rule. Persisting interest in retaining sole prosecutorial discretion in the enforcing agency is far outweighed by the very policy to be enforced. That policy risks substantial frustration if an implied federal right of enforcement is denied. Indeed, private enforcement and public enforcement by the FTC complement one another. The private remedy serves the immediate interest of the consumer in avoiding the burden of having to pay a third-party financer for a performance never received from a seller. Many consumers, however, will not learn of their rights under the rule and will incur the hardship of payment. When these persons are the common victims of a few offending sellers, redress actions brought by the FTC will provide needed relief efficiently. More importantly, coupling civil actions for reformation of contracts with consumer education campaigns instituted by the FTC will help prevent defense cut-off problems from arising at all. After years of ineffective state regulation, private and public enforcement of the rule may be the final blow to the holder-in-due-course doctrine in the credit-sale arena. 